\title{
Pandemi Sürecinde Yabancı Medya Ajanslarının Twitter Paylaşımlarının İçerik Analizi: BBC Türkçe, DW Türkçe ve Independent Türkçe Örnekleri
}

\author{
Turgay Yerlikaya (Dr. Öğr. Üyesi) \\ İstanbul Üniversitesi Illetişim Fakültesi \\ yerlikayaturgay@gmail.com \\ İbrahim Efe (Doç. Dr.) \\ iD Kilis 7 Aralık Üniversitesi İktisadi ve İdari Bilimler Fakültesi \\ ibrahimefe@hotmail.com \\ Kevser Hülya Akdemir (Doktora Öğrencisi) \\ (iD) İstanbul Medeniyet Üniversitesi \\ akevserhulya@gmail.com
}

Başvuru Tarihi: 31.08 .2020

Yayına Kabul Tarihi: 19.11.2020

Yayınlanma Tarihi: 29.01.2021

https://doi.org/10.17680/erciyesiletisim.788251

\section{Öz}

COVID-19 salgın hastalığı 2020 yılında tüm dünyayı etkisi altına almıştır. Ülkelerin farklı stratejilerle mücadele ederek en az zararla atlatmayı amaçladığı bu süreç global ölçekte kamuoyunun yakın ilgisine mazhar olmuştur. Türkiye aldığı erken tedbirler ve sıkı kamu politikaları sayesinde Almanya ve Güney Kore gibi salgınla başarılı șekilde savaşan ülkelerden olmuştur. Salgının oluşturduğu tehdit ve buna bağlı risk unsurlarının iletişiminde medya şüphesiz önemli bir rol üstlenmiştir. Bunların arasında sosyal medya giderek artan kullanıcı sayısı, toplumu ve siyaseti etkileme gücü nedeniyle risk iletişimi açısından da çalışılmaya değer bir veri kaynağı sağlamaktadır. $\mathrm{Bu}$ nedenle mevcut çalışma BBC, Deutsche Welle ve Independent'ın Türkiye temsilciliklerinin Türkçe Twitter hesaplarından 15 Mart-10 Nisan 2020 tarihleri arasında yapılan Koronavirüs paylaşımlarını incelemektedir. İlgili hesaplardan elde edilen veri önceki risk iletişimi çalışmalarında elde edilen ve COVID-19 salgınına özgü etkenlerin yer aldığı bir kodlama tablosuna göre kodlanmış ve bulgular içerik analizi yöntemi ile tahlil edilmiştir. Salgının erken safhalarında ilgili hesaplardan yapılan paylaşımların önemli bir kısmının topluma bilgi verme işlevini taşırken dikkate değer bir bölümünün de siyasi eleştiri amacıyla yapıldığının gösterilmesi çalışmanın en önemli bulgularındandır.

Anahtar Kelimeler: Koronavirüs, Sosyal Medya, BBC Türkçe, DW Türkçe, Independent Türkçe, İçerik Analizi. 


\title{
Content Analysis of Foreign Media Agencies' Social Media Shares in the Pandemic Process: BBC Turkish, DW Turkish, and Independent Turkish Examples
}

\author{
Turgay Yerlikaya (Asst. Prof Dr.) \\ (iD) istanbul University Faculty of Communication \\ yerlikayaturgay@gmail.com \\ İbrahim Efe (Assoc. Prof. Dr.) \\ (iD) Kilis 7 Aralık University Faculty of Economics and Administrative Sciences \\ ibrahimefe@hotmail.com \\ Kevser Hülya Akdemir (Ph.D. Student) \\ (iD) İstanbul Medeniyet University \\ akevserhulya@gmail.com
}

Date Received: 31.08.2020

Date Accepted: 19.11 .2020

Date Published: 29.01.2021

https://doi.org/10.17680/erciyesiletisim.788251

\begin{abstract}
COVID-19 pandemic disease has affected the whole world in 2020. This process, which countries aim to overcome with the least damage by struggling with different strategies, has received the attention of public opinion on a global scale. Through early measures and its robust public policy, Turkey has been one of the most successful countries in fighting the epidemic, such as Germany and South Korea. The media undoubtedly has played an important role in communicating the threat posed by the pandemic and the associated risk factors. Among these, social media provides a data source worth studying in terms of risk communication due to its increasing number of users and its power to influence society and politics. Therefore, the present study investigates Twitter messages of the Turkish accounts of the BBC, the Deutsche Welle, and the Independent shared between March-10 April 2020. The data obtained from the relevant accounts were coded according to a coding table obtained in previous risk communication studies and containing factors specific to the COVID-19 outbreak, and the findings were analyzed by content analysis method. It is one of the most important findings of the study that while a significant part of the messages shared by the relevant accounts in the early stages of the pandemic has the function of informing the society, a remarkable part of them is for political criticism.
\end{abstract}

Keywords: Coronavirus, Social Media, BBC Türkçe, DW Türkçe, Independent Türkçe, Content Analysis. 


\section{Giriş}

Çin'in Hubei eyaletinin yönetim merkezi ve en büyük şehri Wuhan kentinde ortaya çıktığı iddia edilen COVID-19'un Çin sınırlarını aşarak önce Avrupa'ya sonrasında da ABD'ye yayılması, salgının DSÖ tarafından pandemi olarak ilan edilmesini kaçınılmaz kıldı. Ölçek itibariyle küresel bir boyut kazanan bu durum, insanlık tarihinin gördügü en büyük kriz ve tehditlerden birisi olarak değerlendirilmektedir (Kissenger, 2020).

$\mathrm{Bu}$ ölçekteki bir küresel salgında sadece devletlerin değil, ulus-üstü birliklerin de mücadelede yetersiz kalması gelecekteki tartışmaların yönünü belirlemektedir. Etki düzeyi sadece sağlık alanı ile sınırlı kalmayan pandemi süreci, birbirine entegre olan ekonomi, siyaset ve toplumsal hayatı da ciddi sorunlarla yüzleșmek durumunda bırakmıştır. Yaşanan bu krizin önümüzdeki süreçte küresel dönüşümlerin habercisi olacağı ve uluslararası sistemde önemli kırılmalar yaratacağı beklentisi, şimdiden yoğun biçimde tartışılmaktadır. Nitekim Dünya Sağlık Örgütü ve AB gibi yapıların yanı sıra küresel güç dengesinde başat konumda olan ülkelerin pandemi ile mücadelede başarısız olması, dönüşüm tartışmalarının ne denli ciddi olduğunu göstermektedir. Bu anlamda, modern dünyanın en büyük krizlerinden birisi olan pandeminin ne kadar süreceği ve ne kapsamda tahribat yaşatacağı, dönüşümün niteliğini belirleyecek en önemli husustur (Hanioğlu, 2020).

İtalya, İspanya ve İngiltere gibi Avrupa ülkelerinin yanı sıra ABD’nin de Koronavirüsle mücadelede yetersiz kalması, güç unsurunun sadece ekonomik ve askeri kapasitelerle tanımlanamayacağı tezini güçlendirdi (Habermas, 2020). Hâlihazırda süreci görece başarılı yürüten ülkelere bakıldığında, sağlık sistemi ve medikal donanım açısından uzun yıllara dayanan bir strateji ile hareket ettikleri görülmektedir. Türkiye, Güney Kore ve Almanya örneklerinde olduğu gibi, krizi ciddiye alan ve tedbirler konusunda proaktif politikalar ortaya koyan ülkeler, bu anlamda başarılı sayılmaktadır. Hem toplumsal alanda uygulanan sosyal izolasyonun hem de devletin kurumsal kapasitesinin başarısı sonucunda ortaya çıkan senkronizasyon, bu ülkelerin pozitif biçimde ayrıştırılmasını ve kategorize edilmesini mümkün kılmaktadır.

Ülkede ilk vakanın tespit edildiği 11 Mart tarihinin ardından, sağlık bakanlığının ve hükümetin aldığı önleyici tedbirler, Türkiye'nin pandemi ile şu ana kadarki mücadelesinin pozitif ayrışmasını etkileyen hususlardır. Nitekim Türkiye sürecin hemen başında, ilk ve orta öğretimin yanı sıra üniversitelerdeki eğitimleri askıya almış, toplu ibadet mekânları olan cami ve mescitleri kapatmış, alışveriş merkezi ve restoranlara kısıtlamalar getirmiş, müze ve örenlerin kapatılmasının yanı sıra mobilizasyonu asgariye indirme adına uçuşların askıya alınması gibi bir dizi önlem almış ve birçok ülkeye oranla bu tedbirleri erken tarihlerde gerçekleştirmiştir.

Yakın geçmişteki kriz tecrübelerini (örneğin depremler ve sığınmacı krizi) sahaya yansıtan Türkiye salgın ile ilgili süreçte "kriz iletişimi" noktasında da başarılı bir sınav vermektedir. İlk vakanın görüldüğü tarihten bugüne, krizi başarılı biçimde yöneten başta İletişim Başkanlığı ve Sağlık Bakanlığı olmak üzere ilgili bürokrasi kanalları, periyodik olarak vatandaşları bilgilendirmiş ve teşkil ettiği bilim kurulu ile de kitlelerin bu konudaki bilgi ihtiyacını karşılamıştır. Bu eş zamanlı kriz yönetimi, kitleleri doğru bilgi ile bilgilendirdiği gibi sürecin en az kaygı ile tamamlanmasını ve psikolojik etkileri asgari düzeye indirmeyi de hedeflemiştir. Türkiye'nin özellikle bu süreçte sorunu ele alış şekli ve uyguladığı kendine özgü yöntemler (örneğin filyasyon çalışmaları), batılı medya organları tarafından ara sıra takdir edilse de Batı medyasının Türkiye temsilcileri nezdinde benzer ilgiyi 
görememiş, dahası takipçilerine iç siyasetteki kutuplaşma çerçevesinden aktarıldığı için önemsizleştirilmiştir. Öyle ki sürecin hemen başında, Türkiye'nin virüsle mücadeledeki yöntemini sorunsallaştıran haberler, dezenformasyon ve manipülatif içeriklerin en kaba biçimlerini bu mecralarda dolaşıma sokmuştur. Bu bağlamda, özellikle Batı medyasının Türkiye'ye ilişkin tavrı, olgular üzerinden analiz ve içerik üreten bir habercilik dili yerine imal edilmiş algılar ile şekillenen bir pratiğe yerini bırakmaktadır. Hiç kuşkusuz, inceleme için seçilen medya organlarının pandeminin Türkiye'deki serüvenine ilişkin tavrı, sosyal medya ortamlarında da karşılık bulmakta ve ortaya çıkan etkileşim sonucunda ciddi bir bilgi kirliliği söz konusu olmaktadır.

Çalışmanın odak noktasını uluslararası basın yayın organları olan BBC, Deutsche Welle ve Independent'ın Türkiye temsilciliklerinin 15 Mart-10 Nisan 2020 tarihleri arasındaki Twitter hesaplarından yapılan Koronavirüs paylaşımlarından oluşturulan özel bir derlemin karşılaştırmalı incelenmesi teșkil etmektedir. Elde edilen veriler bu çalışma için geliştirilen özel bir kodlama yöntemi ile belirli kategorilere ayrıştırılacak ve nihai evrede içerik analizi yöntemi ile çözümlenecektir. Bu çalışmanın en temel amacı COVID-19 salgınının Türkiye'de görülmeye başlamasıyla birlikte sosyal medyada yer bulan ve gündem oluşturan söylemleri tespit etmek ve bu söylemlerin içerik analizini yapmaktır.

\section{2. Çalışmanın Tasarımı}

Çalışmanın temel sorusunu cevaplamak için elde edilen örneklem, Türkiye'de faaliyet gösteren 3 önemli yabancı basın kuruluşunun (BBC, Independent, Deutsche Welle) Twitter hesaplarında COVID-19 ile ilgili 1119 paylaşımı kapsamaktadır. 2006 yılında kurulan ve bir mikroblog platformu olan Twitter zaman içerinde en fazla kullanılan sosyal medya platformlarından biri haline geldi (Pew Research Center, 2015). 9.6 milyon kullanıcısı ile Twitter, Türkiye'de en sık ziyaret edilen ilk 20 sayfa arasında yer almaktadır (TranslateMedia, 2020). Makalenin yazıldığı tarih (18.04.2020) itibariyle @ bbcturkce'nin 3,5 milyon, @dw_turkce'nin 617.6 bin ve @TurkishIndy'nin 242.2 bin takipçisi bulunmaktadır. Söz konusu örneklemlerin seçilmesi, bahse konu mecraların Türkiye'deki takipçi sayılarının yanı sıra gündem oluşturma açısından ciddi öneme haiz olmaları nedeniyledir. İlgili hesaplardan yapılan COVID-19 temalı paylaşımlar bir araștırmacı tarafından özel bir yazılım kullanılarak toplandı ve tarih sıralamasına göre düzenlendi. Verinin bir kısmı (yaklaşık 50 Twitter paylaşımı) 3 araştırmacı tarafından bağımsız olarak kodlanarak aşağıda açıklanan kodlama tablosu geliştirildi. Kodlamaların erken safhasında verinin \%10'luk kısmı ikinci bir araștırmacı tarafından da bağımsız olarak kodlandı. Kodlayıcılar arasında belirli bir tutarlılığa erişebilmek için kodlayıcı güvenirliği testi uygulandı. Tutarlılık değerlerinin düşük olduğu kategoriler yeniden elden geçirildi ve kategorilerdeki değerlerin ne anlama geldiği daha açıklayıcı bir şekilde kodlayıcıya aktarıldı. Kodlama aşamasında görev alan kodlayıcının kendi yorumlarını en aza indirmek için hangi kategoride hangi değerin ne anlama geldiğiyle ilgili kodlayıcıya yazılı ve sözlü olarak bilgiler verildi.

\subsection{Kodlamalar}

Kodlamaların ilk aşamasında indirilen paylaşımlar Excel ortamında kodlama tablolarına aktarıldı. Kodlama tabloları araştırma sorusuna uygun olarak hazırlandı ve ön inceleme sonrasında geliştirildi. Kodlama tablosunda yer alan kategorilerin önemli bir kısmı daha önce yapılan sosyal medya çalışmalarından uyarlandı (Lovejoy \& Saxton, 2012; Neiger, Thackeray, Burton, Thackeray, \& Reese, 2013; Park, Reber, \& Chon, 2016; Park, Rodgers, \& Stemmle, 2013). 
İlk olarak Twitter özelliklerinin etkileşime etkisini belirlemek üzere basit tanımlayıcı değişkenler kodlamada kullanıldı. Twitter paylaşımının kendisinin de yer aldığı her bir satıra, paylaşımın hangi hesap tarafından yapıldığı, hangi tarihte yapıldığı kaç kez tekrar paylaşıldığı (retweet) ve beğenildiği bilgileri kodlandı. Daha sonra paylaşımın odak noktası (Toplumla İlgili ya da Kurumlarla İlgili) kodlandı. Odak noktası toplumun COVID-19 ile ilgili bilgilendirmeleri olan paylaşımlar ilk gruba, odak noktası ilgili kurumların toplumun ve bireylerin sağlı̆ını ve bilgilendirilmesini hedefleyen paylaşımları ikinci gruba alındı. Sonraki adımda paylaşımlar Lovejoy ve Saxton'nun (2012) yaklaşımından esinlenerek işlevleri açısından üç gruba ayrıldı: bilgi, eleştiri ve övgü. COVID-19 salgını ile ilgili bilgi paylaşımı yapmayı amaçlayan paylaşımlar "bilgi" işlevi ile kurumların ve kişilerin salgınla ya da etkileri ile ilgili aldığı ya da almadığı kararları ve icraatlarını eleştiren paylaşımlar "eleştiri" işlevi ile ve kurumların ve kişilerin salgınla ya da etkileri ile ilgili aldığı kararları ve icraatlarını öven paylaşımlar "övgü" işlevi ile kodlandı. Daha sonra her bir grupta yer alan paylaşımların göze çarpan ilk konusu kodlandı. "Çerçeveler" kategorinde konunun hangi çerçeveden ele alındığı ile ilgili olarak her bir paylaşıma "Kamu, Ekonomi, Siyaset ve Sağlık" kodlarından biri atandı. Son olarak ilgili literatür ve COVID-19 salgını dikkate alınarak paylaşımların içerdiği risk algısı etkenleri belirlendi.

Risk iletişimi literatürü risk bilgisinin nasıl işlendiğini, risk algılarının nasıl oluşturulduğunu ve risk kararlarının nasıl alındığını tanımlayan 4 kuramsal modele dayanmaktadır. (Covello, 1998; Covello \& Sandman, 2001). Bunlar; Risk Algısı Modeli (Risk Perception Model), Zihinsel Gürültü Modeli (Mental Noise Model), Olumsuz Baskınlık Modeli (Negative Domiance Model) ve Güven Belirleme Modelidir (Trust Determination Model).

Risk Algısı Modelinde risk algısının pek çok duygu tarafından belirlendiğine ve bunların risk algı derecesini değiştirdiğine inanılmaktadır (Covello \& McCallum and Pavlova, 1989; Slovic, 1987; Rogers, 1997; Wildavsky \& Dake, 1990; Renn, Bums, Kasperson, Kasperson, \& Slovic, 1992). Buna göre korku, endișe ve terör duygularını uyandıran riskler uyandırmayanlara göre daha büyük olarak algılanmaktadır (Covello \& McCallum and Pavlova, 1989). Bu duygular, riske dair algıların öznel değerlendirmesine yol açarken bireylerin davranışlarını ve söz konusu tehdide verdikleri cevapları da belirlemektedir (Guidry, Jin, Caroline, Messner, \& Meganck, 2017). Benzer şekilde bilginin işlenme şeklinin iletişimi nasıl etkilediğiyle ilgili olan Zihinsel Gürültü Modeli insanların stres altında bilgiyi nasıl işlediklerine odaklanmaktadır (Covello \& McCallum and Pavlova, 1989). Zihinsel gürültü insanlar tehdit edildiklerini hissettiklerinde ya da ciddi endișe duydukları durumlarda ortaya çıkmakta (Glik, 2007; J.Baron, C.Hershey, \& Kunreuther, 2000) ve iletişim için gerekli olan bilgi işleme, karar alma ve hafızaya alma gibi süreçleri bozmaktadır (G.Cairns, Andrade, \& MacDonald, 2013; Covello, Peters, \& Wojtecki, 2001; Glik, 2007). Bu tür olumsuz bilgi işleme süreçlerinin neden daha baskın olduğunu açıklamaya çalışan Olumsuz Baskınlık Modeli modern psikolojideki merkezi bir önermeye dayanmaktadır: insanlar kayıplara (olumsuz sonuçlara) kazançlardan (olumlu sonuçlar) daha fazla önem vermektedir (Maslow, 1970). Bu modelin stratejik risk iletişimi uygulamaları açısından önemi ise olumsuz bir mesajın daha fazla olumlu ve çözüm odaklı mesajla dengelenmesi gereğidir (Covello, 1998). Tüm risk iletişimi stratejilerinin ortak noktası ise güven duygusuna olan ihtiyaçtır (Renn, Bums, Kasperson, Kasperson, \& Slovic, 1992; P. Slovic, 1999; Peters, Covello, \& McCallum, 1997). Güven Belirleme Modeline göre kriz durumlarında etkili iletişimin başarısı güven duygusuna bağlıdır, güven duygusunun tesis edilmesi önemli bilginin işlenmesi ve hatırda tutulması ve dolayısıyla tavsiye 
edilen eylemlerin gerçekleştirilmesi için elzemdir (Covello, Peters, \& Wojtecki, 2001; B. J. Reynolds, 2009).

Yukarıdaki risk iletişimi literatürü dikkate alınarak yapılan kodlamalar neticesinde elde edilen bulgular kodlamalarda yer alan değişkenlerin dağılımının gösterilmesi için sıklık sonuçları ile incelendi. Ayrıca Excel'de pivot tablolar oluşturularak kodlama kategorileri ilişkisel olarak da analiz edildi.

Bu çalışmada elde edilen örneklem, COVID-19 ile ilgili paylaşımların kısıtlı ve erken bir dönemini kapsamaktadır ve bu nedenle diyakronik olarak yapılacak gelecek çalışmalarla geliştirilebilir. Ayrıca risk iletişimi açısından bu çalışmada Türkiye'de temsilciği bulunan pek çok yabancı haber ajans arasından sadece 3 tanesi seçilmiştir. Ancak BBC, Independent ve Deutsche Welle hem uluslararası etkileri açısından hem de Türkçe hesaplarının takipçi sayısı açısından temsil gücü yüksek bir veri seti sağlamaktadır.

\section{Bulgular}

İçerik analizinde çalışma için geliştirilen bir kodlama tablosu (Bkz. Ekler, Tablo 7) kullanılarak Deutsche Welle Türkçe, Independent Türkçe ve BBC Türkçe'nin Twitter hesaplarından yapılan COVID-19 salgını ile ilgili 1118 Twitter paylaşımı incelendi. Paylaşımların hesaplara göre dağılımı Tablo 1'de gösterilmektedir. Elde edilen bulgular çalışmada kullanılan analitik kategorilerin sırasına göre sunulacaktır.

Tablo 1. Verinin Hesaplara Göre Dağılımı

\begin{tabular}{|l|c|}
\hline Hesap & Paylaşım Sayısı \\
\hline BBC Türkçe & 404 \\
\hline dw_turkce & 326 \\
\hline Turkishlndy & 388 \\
\hline Genel Toplam & 1118 \\
\hline
\end{tabular}

\subsection{Etkileşim}

Sosyal medya araçları kullanıcılara kendi aralarında etkileşim imkânı tanımasının yanı sıra kurumlarla da doğrudan diyalog kurabilme imkânını tanımaktadır (McAllister \& Spooner, 2009; Sommerfeldt, Kent, \& Taylor, 2012). Teknolojik gelişmelerin kriz iletişimini nasıl dönüştürdüğünü inceleyen çalışmalarında Veil, Buehner, ve Palenchar (2011) tarafından yeni medya kullanıcılarının "aynı anda hem bilgi tüketicileri hem de bilgiye katkı sağlayanlar” olarak adlandırıldığı yukarıda ifade edilmişti.

Etkileşimin tespiti konusunda sosyal medyanın iletişim çalışmalarına önemli bir katkı sağlama potansiyeli bulunsa da bu tam anlamıla gerçekleşmiş değildir (Alhabash \& Mcalister, 2014; Bortree \& Seltzer, 2009; Lovejoy \& Saxton, 2012). Twitter, kullanıcılarına diğer kullanıcılarla etkileşim için iki seçenek sunmaktadır: retweet ve beğenme (favoriting). Bu çalışmada her bir Twitter paylaşımının etkileşim skoru paylaşımın retweet sayısı ve beğenilme sayısı toplamı ile hesaplanmıştır. Etkileșim skoru yüksek olan ilk 10 paylaşımın hesaplara dağılımı aşağıdaki tabloda gösterilmektedir. 
Tablo 2. Paylaşımların Etkileşim Skorları

\begin{tabular}{|c|c|c|c|c|c|c|c|}
\hline & Tweet & Hesap & Tarih & Beğeni & Retweet & $\begin{array}{l}\text { Etkileşim } \\
\text { Skoru }\end{array}$ & Risk algısı \\
\hline 1 & $\begin{array}{l}\text { "Türkiye'de en az } 32 \text { milyonun enfekte } \\
\text { olacağı tahmin ediliyor" "Bu } 150 \text { bin } \\
\text { ile } 600 \text { bin arasında ölüm demek" } \\
\text { "En a... https://t.co/jP13NY9EN }\end{array}$ & dw_turkce & 23.03 .2020 & 9808 & 5781 & 15589 & Tehlike \\
\hline 2 & $\begin{array}{l}65 \text { yaş üstü vatandaşlara yardım amacıyla } \\
\text { kurulan "Vefa Sosyal Destek" } \\
\text { grubunda görevli askerler, Van'ın Edremit } \\
\text { ilç... https://t.co/mxpvNMyNDz }\end{array}$ & dw_turkce & 28.03.2020 & 8794 & 993 & 9787 & Dayanışma \\
\hline 3 & $\begin{array}{l}\text { Türk Tabipler Birliği: “Hekimlerden aldığımız } \\
\text { duyumlar, koronavirüs hastası sayısının } \\
\text { açıklanandan daha fazla olduğu yönünde" } \\
\text { https://twitter.com/bbcturkce/ } \\
\text { status/1239539389698650114 }\end{array}$ & bbcturkce & 16.03 .2020 & 6900 & 2700 & 9600 & Güvensizlik \\
\hline 4 & $\begin{array}{l}\text { "100 kişiye test istiyorsak 1-2'sine yapıllyor" } \\
\text { Türkiye'deki mevcut durumu DW } \\
\text { Türkçe'ye anlatan hekimler, hastanel... } \\
\text { https://t.co/Qbf5szdNJk }\end{array}$ & dw_turkce & 22.03 .2020 & 5857 & 2900 & 8757 & Tehlike \\
\hline 5 & $\begin{array}{l}\text { Ankara Büyükşehir Belediye Başkanı } \\
\text { Mansur Yavaş, öğrenci evleri ve iş } \\
\text { yerlerine Nisan'da fatura yansıtılıayacağını... } \\
\text { https://t.co/JTKloAMgYk }\end{array}$ & bbcturkce & 28.03.2020 & 4388 & 710 & 5098 & Dayanışma \\
\hline 6 & $\begin{array}{l}\text { Sağlık çalışanlarına, Ittfaiyecilere , } \\
\text { Polislere, Süpermarket çalışanlarına } \\
\text { Bizler evde kalırken bizi... } \\
\text { https://t.co/Mlo89vkOHc }\end{array}$ & dw_turkce & 19.03 .2020 & 4008 & 906 & 4914 & Dayanışma \\
\hline 7 & $\begin{array}{l}\text { Her hastaneden bir kişi ne kadar test } \\
\text { yapıldığını ve sonuçlarını biliyor, bilgiler } \\
\text { doğrudan bakanlığa gönderiliyor.... } \\
\text { https://t.co/HVkjshqoeF }\end{array}$ & dw_turkce & 24.03 .2020 & 2919 & 1370 & 4289 & Güvensizlik \\
\hline 8 & $\begin{array}{l}\text { Cerrahpaş̧a Tıp Fakültesi Patoloji Anabilim } \\
\text { Dali eski Ögretim Üyesi Prof. Dr. } \\
\text { Feriha Öz koronavirüs sebebiyle } 87 \\
\text { yaş... https://t.co/KwinKLgXT8 }\end{array}$ & bbcturkce & 2.04 .2020 & 3580 & 562 & 4142 & Tehlike \\
\hline 9 & $\begin{array}{l}\text { Türkiye'de koronavirüs ile nedeniyle } \\
\text { alınan önlemler hızlanırken milyonlarca } \\
\text { insan işe gitmeye devam ediyor. } \\
\text { Evden... https://t.co/RnjVxGmLVh }\end{array}$ & bbcturkce & 29.03 .2020 & 2702 & 752 & 3454 & Tehlike \\
\hline 10 & $\begin{array}{l}\text { Erzurum Valisi: Umreden döndükten } \\
\text { sonra karantinadan kaçan } 28 \\
\text { kissi Çorum'da yakalandı } \\
\text { https://twitter.com/bbcturkce/ } \\
\text { status/1239951357848715271 }\end{array}$ & bbcturkce & 17.03 .2020 & 2700 & 638 & 3338 & Önlem \\
\hline
\end{tabular}

Etkileşim skorunun diğer analitik kategorilerle arasındaki ilişkiye gelince, risk algısı etkenleri açısından en yüksek etkileşim skoruna sahip paylaşımın "tehlike" algısı barındırdığı görülmektedir. Benzer şekilde 4, 8 ve 9 numaralı paylaşımlarda tehlike algısı baskındır. Bilgi işleme süreçlerinde olumsuz duyguların neden daha baskın olduğunu açıklamaya çalışan Olumsuz Baskınlık Modeli modern psikolojideki merkezi bir önermeye dayanmaktadır: insanlar kayıplara (olumsuz sonuçlara) kazançlardan (olumlu sonuçlar) daha fazla önem vermektedir (Maslow, 1970). Bu modelin stratejik risk iletişimi uygulamaları açısından önemi ise olumsuz bir mesajın daha fazla olumlu ve çözüm odaklı mesajla dengelenmesi gereğidir (Covello, 1998). Yukarıdaki tabloda etkileşim skoru en yüksek ilk 10 paylaşımın dördünde baskın risk algısının "tehlike" ve ikisinde "güvensizlik" olduğu, kalan 4 paylaşımda ise olumlu ve nötr risk algısı (dayanışma ve önlem) bulunduğu dikkate alınırsa olumsuz baskınlık modelinin Twitter paylaşımlarında geçerli olduğu düşünülebilir. Independent Türkçe hesaplarından konuyla ilgili paylaşımların diğer iki hesaba göre daha az etkileșim skoruna sahip olmasını hesapların 
takipçi sayılarıyla açıklayabiliriz. Zira bu makalenin yazıldığı tarih (18.02.2020) itibariyle @bbcturkce'nin 3,5 milyon, @dw_turkce'nin 617.6 bin ve @TurkishIndy'nin 242.2 bin takipçisi bulunmaktadır.

\subsection{Odak Noktası}

Bu kategoride Sağlık Bakanlığı, Tabipler Odası, İçişleri Bakanlığı vb. kurumlarla ilgili paylaşımlar "kurumla ilgili" olarak kodlandı. Odak noktası toplumun ve bireylerin sağlığını ve bilgilendirilmesini ilgilendiren paylaşımlar ise "toplumla ilgili" seçeneği ile kodlandı. Paylaşımların odak noktası dağılımına bakıldığında paylaşımların \%61'inin $(n=686)$ toplumla ilgili, \%39'unun $(n=432)$ ise kurumlarla ilgili olduğu anlaşılmaktadır.

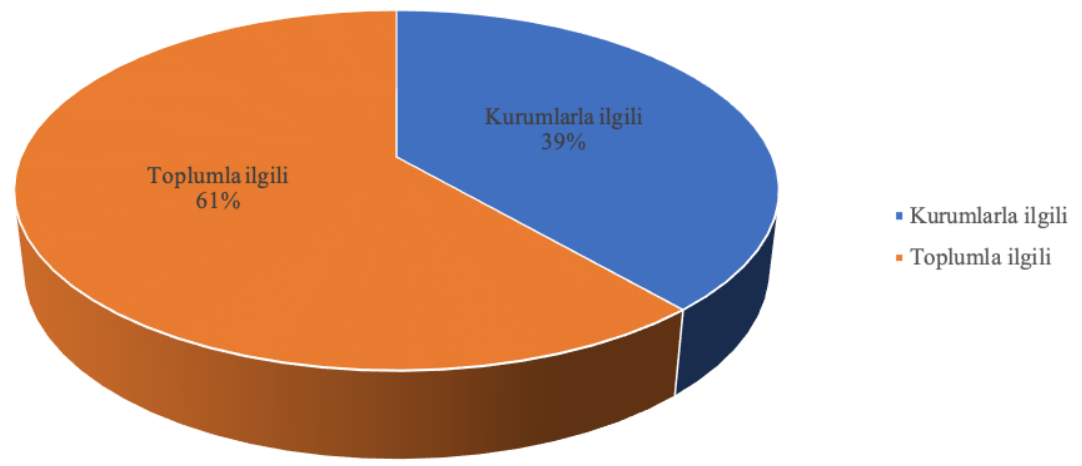

Şekil 1. Paylaşımların Odak Noktası Dağılımı

Odak noktasının hesaplara göre dağılımı aşağıda gösterilmektedir ve hesaplar arasında ciddi bir farklılık yoktur. Bu tabloya göre toplumla ilgili paylaşımlara en fazla Independent Türkçe'de yer verilmiştir. Toplamda \%65 oranında toplumla ilgili tweetlere yer veren Independent Türkçe'nin kurumlarla ilgili paylaşımları ise \%35 oranı ile toplumla ilgili paylaşımlarının yarısından daha azdır. İkinci olarak toplumla ilgili en fazla paylaşımda bulunan hesap BBC Türkçe olmuştur. \%60 oranında toplumla ilgili tweet atan BBC Türkçe'de toplumla ilgili paylaşımlar ve kurumlarla ilgili paylaşımlar birbirine daha yakın bir oran izlemektedir. DW Türkçe ile BBC Türkçe birbirine oldukça yakın sonuçlara sahiptir. DW Türkçe hesabından \%59 oranında toplumla ilgili Tweet atılmıștır. Bu küçük oranla aradaki farkın ve toplumla ilgili paylaşımların en az olduğu hesap DW Türkçe olarak tespit edilmiştir. Her ne kadar toplumla ilgili paylaşımları kurumlarla ilgili içeriklerinden daha fazla olsa da aradaki fark diğer hesaplara kıyasla daha azdır.

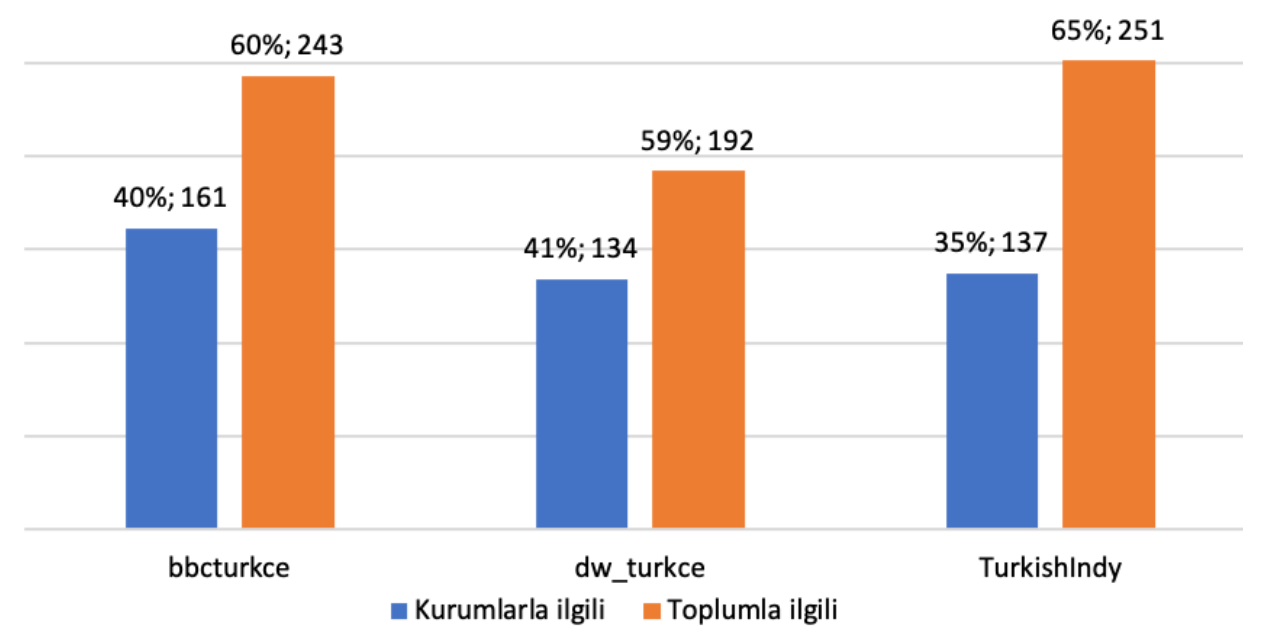

Şekil 2. Paylaşımların Odak Noktasının Hesaplara Göre Dağılımı 


\subsection{Odak Noktası ve İşıvev Arasındaki İlişki}

Her üç hesabın COVID-19 ile ilgili paylaşımlarının odak noktasının ekseriyetle toplumla ilgili olduğu açıktır. Bu bağlamda toplumun ve bireylerin sağlığını ve bilgilendirilmesini ilgilendiren içeriklerin ortaya konulduğu görülmektedir. Bu nedenle hesapların hem toplumla hem kurumlarla ilgili paylaşımlarının işlevinin büyük oranda "bilgi" olduğu tespit edilmiştir. Kurumlarla ilgili paylaşımlarda "eleştiri" işlevine de sıkça yer verildiği Şekil 3'ten anlaşılmaktadır. Övgü işlevi ise her iki odak noktası için de oldukça düşük bir seviyede kalmıştır. Bilgi veren tweetlerin \%70'i toplumla, \%30’u kurumlarla ilgidir. Eleştirel tweetlerin ise \%65'i kurumlarla ilgili, \%35'i ise toplumla ilgilidir. Övgü içerikli paylaşımların \%56 ile önemli bir kısmının kurumlara yönelik olduğu, \%44'ünün ise toplum hakkında olduğu görülmüştür. Özetle, hesapların toplumla ilgili paylaşımlarında bilgi işlevinin ön planda olduğu, kurumları konu edinen paylaşımlarında ise bilgi ile birlikte eleştiri işlevinin de oldukça yüksek bir seviyede bulunduğu görülmektedir.

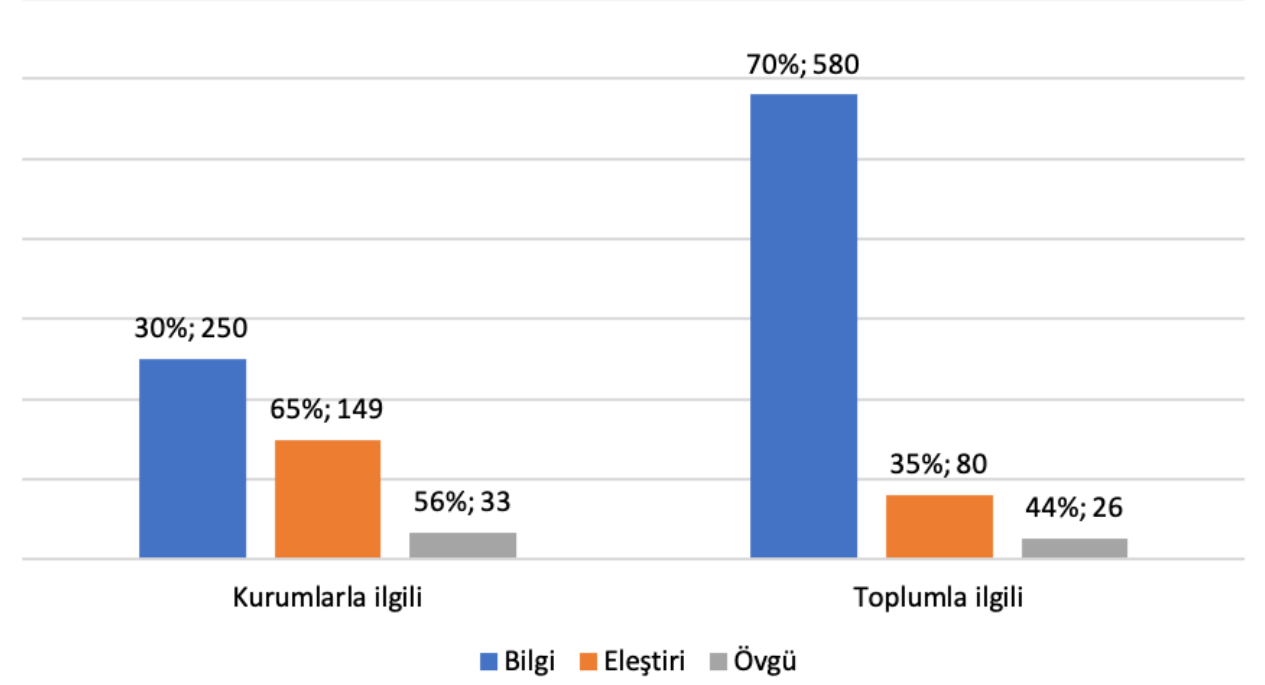

Şekil 3. Odak Noktası ve İşlev Arasındaki İlişki

\subsection{Odak Noktası ve Çerçeve Arasındaki İlişki}

Daha dikkate değer bir bulgu odak noktası ve çerçeve kategorileri karşılaştırıldığında ortaya çıkmaktadır. Hesapların ilgili Twitter paylaşımları ekonomi, kamu, sağlık ve siyaset olmak üzere 4 farklı çerçeveye göre kodlanmıştır. Buna göre toplumla ilgili paylaşımların önemli bir kısmının sağlık ve kamu çerçevelerinden ele alındığı görülmektedir. Kamuya ait paylaşımların \%73'ü toplumla \%27'si ise kurumlarla ilgilidir. Sağlıkla ilgili tweetlerin ise \%84'ü toplumla ve \%16'sı kurumlarla ilgilidir. Yani toplum sağlığının, salgın kapsamında alınan idari tedbirlerin ve kamuyu ilgilendiren önlemlerin ön plana çıkarıldığı görülmektedir. Odak noktası kurumlarla ilgili olan paylaşımların ise en fazla siyasi çerçeveden aktarıldıkları görülmektedir. Siyasetle ilgili paylaşımların \%80'i kurumları ve yalnızca \%20'si toplumu merkeze almıștır. Şimdiye kadar incelenen kategorilere göre hesapların odak noktası kurumlarla ilgili olan paylaşımlarını daha çok siyasi çerçeveden ele aldığı ve bu paylaşımlarda bilgi ve eleștiri işlevlerinin baskın olduğu görülebilir. Toplumla ilgili paylaşımlarının ise kamu yönetimi ve sağlıkla ilgili konularda bilgi vermek amacıyla paylaşıldıkları görülmektedir. 


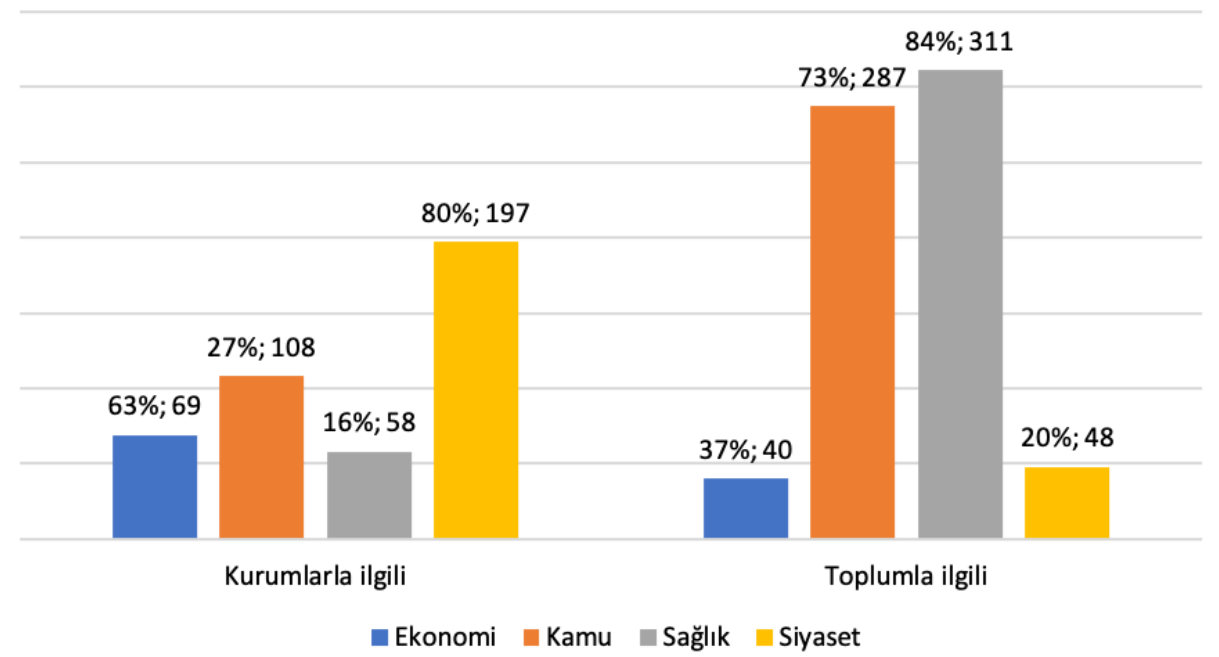

Şekil 4. Odak Noktası ve Çerçeveler Arasındaki İlişki

\section{5. İslev}

Bu çalışmada COVID-19 ile ilgili paylaşımlar işlevlerine göre 3 gruba ayrılmıştır; eleştiri, övgü ve bilgi. Tüm paylaşımların işlevlerine göre dağılımı aşağıda gösterilmektedir. Buna göre incelenen hesapların en fazla (\%74) bilgi işlevi ile kodlanan paylaşım çeşidine öncelik verdiği görülmektedir. Bu oranı \%21 ile eleştiri takip etmektedir. Övgü ise \%5 ile oldukça düşük bir seviyede kalmıştır.

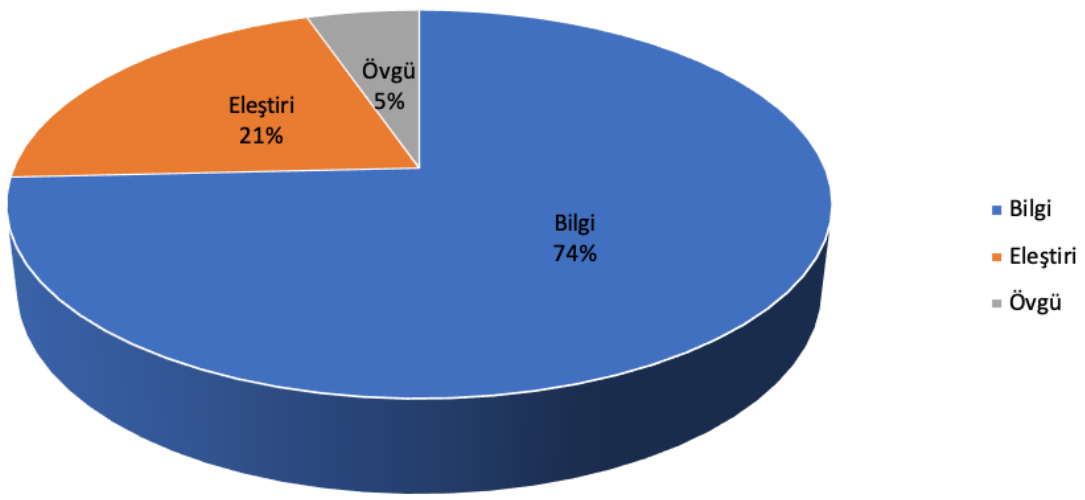

Şekil 5. Paylaşımların İşlev Dağılımı

Hesaplara göre işlevlerin dağılımı aşağıdaki tabloda yer almaktadır. Tüm hesaplarda bilgi işlevi en yoğun iken, eleştiri işlevi ikinci ve övgü üçüncü sırada gelmektedir. 


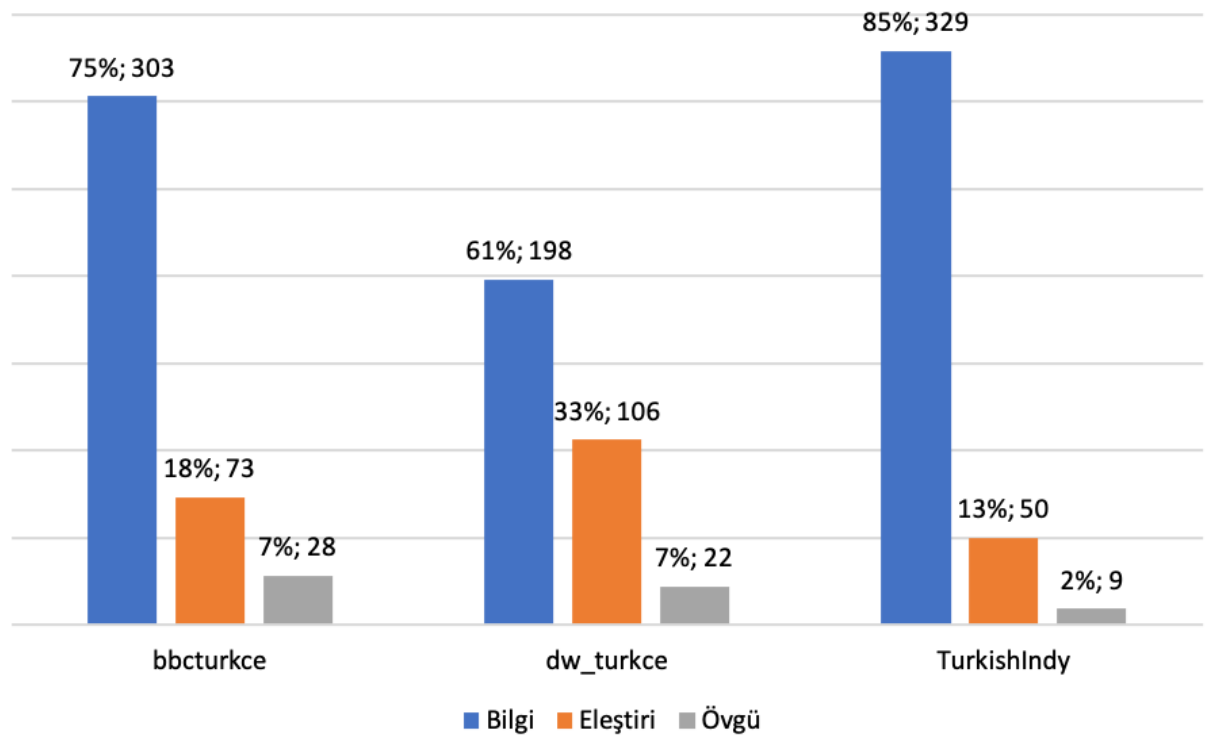

Şekil 6. Paylaşımların Hesaplara Göre İşlev Dağılımı

Bilgi işlevinin en yüksek olduğu hesap Independent Türkçe olarak belirlenmiştir. Independent Türkçe'nin paylaşımlarının \%85'i bilgi işlevi ile kodlanırken \%13'ü eleştiri ve \%2'si övgü içermektedir. BBC Türkçe'de paylaşılan tweetlerin ise \%75'i bilgi, \%18'i eleştiri ve \%7'si övgü işlevlidir. Tabloya göre DW Türkçe tweetlerinin \%61'i bilgi, \%33'ü eleştiri ve \%7'si övgü ağırlıklıdır. Buna göre eleştiri işlevi güden paylaşımların en fazla (\%33 ile) yer aldığı hesabın DW_Turkçe olduğu görülmektedir. DW Türkçe paylaşımlarının önemli bir bölümünde sağlık politikalarının eleştirilmesinde Türk Tabipler Birliği'nden alıntı yapılmaktadır. Sağlık politikaları ile ilgili alınan kararlardaki "geç kalmışlık" ya da "yanlışlık", aşağıdaki örneklerde görüleceği üzere eleștirinin temel çerçevesini oluşturmaktadır:

- “Türkiye'de COVID-19 testinde geç kalındı" Türk Tabipleri Birliği test konusunda Sağlık Bakanlı̆̆ı'nın geç kaldığını söylüyor Uzmanlara göre koronavirüs salgınının önüne geçilebilmesi için test yapılan sağlık kuruluşlarının artırılması şart \#COVID19tr https://t.co/u29Kw8MTi1

- Kaç sağlık personeli hastalığa yakalandı Türk Tabipleri Birliği'nden Sağlık Bakanı Fahrettin Koca'ya Türkiye'de koronavirüse ilişkin 19 soru https://t.co/pfo0waplHv

Eleştiri işlevli paylaşımların özellikle salgının ekonomik boyutu ve hükümetin ekonomi politikalarına yoğunlaștığı aşağıdaki örnek paylaşımlarda görülebilir;

- "Korona gelmeden önce de ciddi bir işsizlik sorunu vardı. Bu salgın işsizlik sorununa tüy dikmiş oldu. Mevcut işsizlerin yarısı kadar daha yeni işsiz beklenebilir" Prof. Dr. Sayan'a göre Türkiye salgına işsizlik açısından kötü bir zamanda yakalandı. https://t. co/rEDVqJ1I9f

- "İçinde bulunduğumuz dönem, bütçe açığını düşünecek bir dönem değil maalesef" "Olağanüstü dönemlerde devletler elektrik, su, doğalgaz parası almazlar" \#Koronavirüs önlemlerinin maliyeti kamu kaynaklarından karşılanamaz mı? DW \#Haber'de. https://t.co/60QxRHeb7g

BBC Türkçe'nin eleştiri işlevli paylaşımları da DW Türkçe ile konu olarak benzerlik göstermektedir. Sağlık, siyaset ve ekonomi başlıca eleştiri temalarını oluşturmaktadır. BBC Türkçe, sıkça işçilerle ilgili haberleri de gündeme getirmiş, hem şehirdeki işçilerin 
hem tarım işçilerinin çalışma koşulları ile ilgili konuları eleştirel bir perspektiften işlemiştir. BBC Türkçe'nin bahsi geçen konulara dair örnek paylaşımları aşağıdaki gibidir;

- Türkiye'deki yoğun bakım doktorları anlatıyor: Koruyucu ekipman sorununun büyük bir kısmını aştık ama işler çığırından çıkmaya başlamış durumda. Dün hayatımda geçirdiğim en kötü günlerden biriydi. Çok fazla hasta geldi, içlerinde genç hastalar da vardı.»https://t.co/qMQlphjm2p

- Koronavirüs günlerinde çalışmak zorunda olan işçilerin yaşadığı problemlerden biri de ulaşım. BBC Türkçe işçilerin bu dönemde yaşadığı sorunları araştırdı. https://bbc. in/2XcTuLy https://t.co/iF60CXhg2L

- Türkiye'de koronavirüs ile nedeniyle alınan önlemler hızlanırken milyonlarca insan işe gitmeye devam ediyor. Evden çalışılması mümkün olmayan sektörlerdeki işçiler ve esnaf hangi koşullarda çalışıyor? https://bbc.in/2yjd4eP

- Türkiye ekonomisinin koronavirüs salgınının yarattığı krizle başa çıkması için ne yapılmalı? https://t.co/8sNlgdaV3n

Independent Türkçe'de eleştirel haberlere daha çok farklı parti başkanlarının sözleri aracılığıyla yer verildiği anlaşılmaktadır. Hükümet eleştirisinin parti başkanlarınca gündeme getirilmesi Independent Türkçe'nin haberlerine yansımıștır. Ayrıca sık sık COVID-19 tedbirleri bağlamında hazırlanan infaz yasa tasarısına dair eleştirilere de rastlanmaktadır. İnfaz düzenlemesinin adil olmadığı ve siyasi suçluları da kapsaması gerektiği, büyük oranda HDP'li vekillerin ifadeleriyle haberleștirilmiștir. Independent Türkçe'de bahsi geçen konulara dair eleştiriler aşağıdaki örneklerde görülebilir:

- Akşener: Kendi vatandaşından para isteyerek zedeledikleri itibarı, Avrupa'ya yardım ederek toplamaya çalışıyorlar.

https://twitter.com/TurkishIndy/status/1247391844297854977

- HDP Grup Başkanvekili Beştaş: Hayat cezaevine sığmaz, hukukun üstünlüğü herkes için uygulanmalıdır. https://twitter.com/TurkishIndy/status/1247973738831908867

- Tutuklu eski Hakkari Belediye Başkanı Hatipoğlu'nun oğlu: Annemi koronavirüsten kaybetmek istemiyorum.

https://twitter.com/TurkishIndy/status/1244000055369043968

Eleștiri işlevli paylaşımların tematik dağılımı Şekil 8'de gösterilmektedir. Buna göre eleştiri işlevi en fazla siyasi temalı içeriklerde öne çıkmaktadır. BBC Türkçe ve DW Türkçe'nin eleștiri işlevli tweetlerinin \%52'si siyaset temalıdır. BBC Türkçe'nin eleştirel tweetlerinin ikinci sırasında \%26 ile sağlı teması, \%15 ile kamu ve \%7 ile ekonomi yer almaktadır. DW Türkçe'nin ikinci sırasında ise \%22 ile ekonomi, \%16 ile sağlık ve \%10 ile kamu bulunmaktadır. Independent Türkçe'nin eleştirel tweetlerinin \%46'sı siyasetle ilgili, \%24'ü sağlıkla, \%18'i ekonomiyle ve \%12'si kamuyla alakalıdır. Bu bağlamda DW Türkçe'nin salgına dair içerik üretirken en fazla eleştiriye yer veren hesap olduğu ve siyaseti merkeze alan paylașımlarında yoğun şekilde eleștirel yorumlara yer verdiği söylenebilir. 


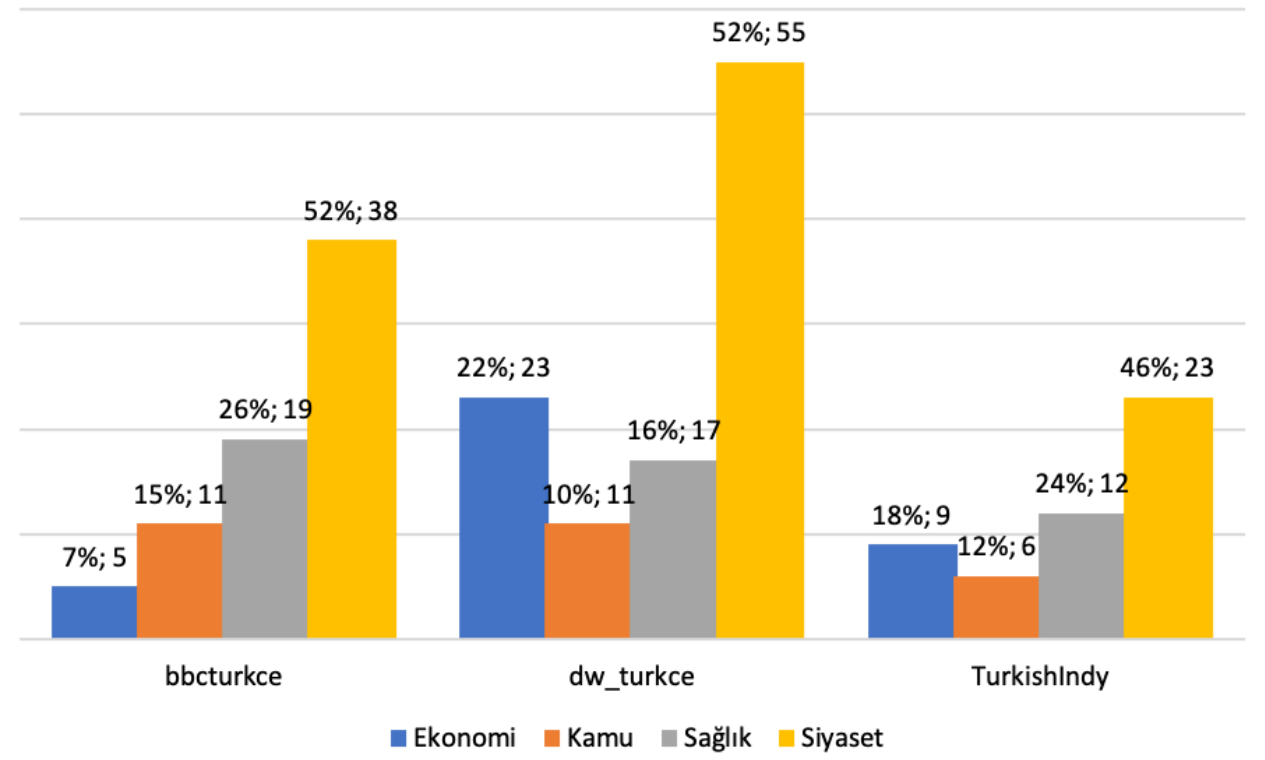

Şekil 7. Eleştiri İşlevli Paylaşımların Tematik Dağılımı

Eleştiri işlevli paylaşımlarının örnekleri aşağıda görselleriyle beraber verilmektedir.

DW Türkçe @dw turkce.7 Nis

"Korona tehdidi muhtemelen 3-5 ay içinde geçecek ama ne yazık ki özgürlüklerimiz üzerindeki baskı, tehdit ve yıldırma girişimleri bitmeyecek"

TBMM'deki yeni infaz düzenlemesinin gazeteciler için daha zor bir dönemi bașlatacağı endișesi hâkim

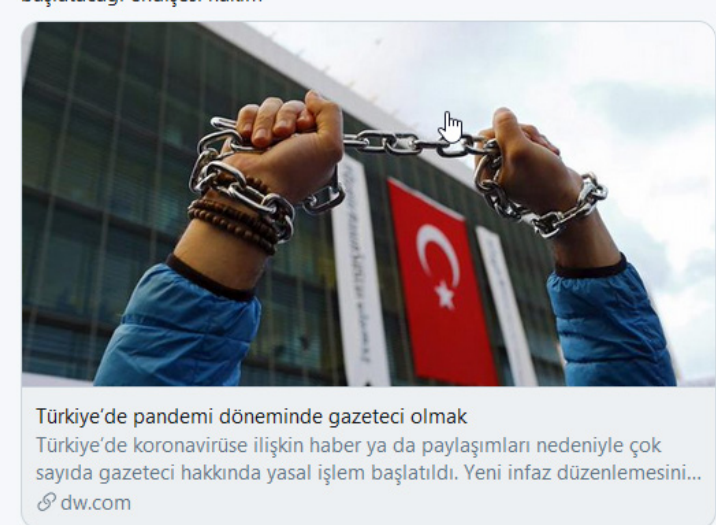

Dw DW Türkçe @ @dw_turkce.23s

"Maliye Bakanı'nın 4,5 milyon aileye, biner lira yardım yapılacağını duyurması Türkiye'deki korkunç sadaka yönetimi anlayışının bir sonucudur"

Iş̧̧̧ örgütlerine göre, işsizlik sigortası fonu ve adil bir vergilendirme sisteminin hayata geçirilmesi gerekiyor

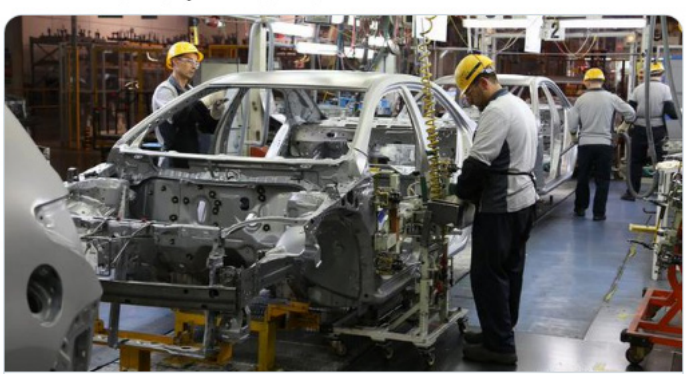

Işçiler hükümetten kalıcı çözüm istiyor

Türkiye'de hükümet koronavirüsle mücadele kapsamında maddi yardım

yapılacak aile sayısını 4,5 milyona çıkardı. Ancak ișçi örgütleri ve ...

$\mathcal{O} \mathrm{dw} . c o m$
Q 18
ใ】 78
O 259
个

Görsel 1. DW Türkçe'nin Siyaset ve Ekonomi Çerçevelerine Dair Eleștiri Ișslevli Haber Örnekleri: DW Türkçe, 7 Nisan 2020 ve DW Türkçe, 10 Nisan 2020 
BBC News Türkçe

@bbcturkce

Türk Tabipleri Birliği: Türkiye göz göre göre enfekte hale getirildi bbc.in/2WTymcZ

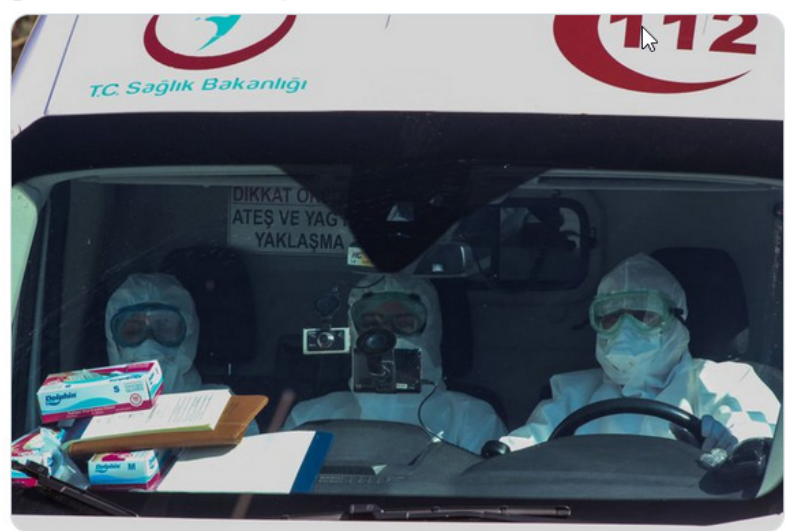

BBC News Türkçe

@bbcturkce

HDP Eş Başkanı Mithat Sancar: İktidar salgını fırsat gibi görüyor

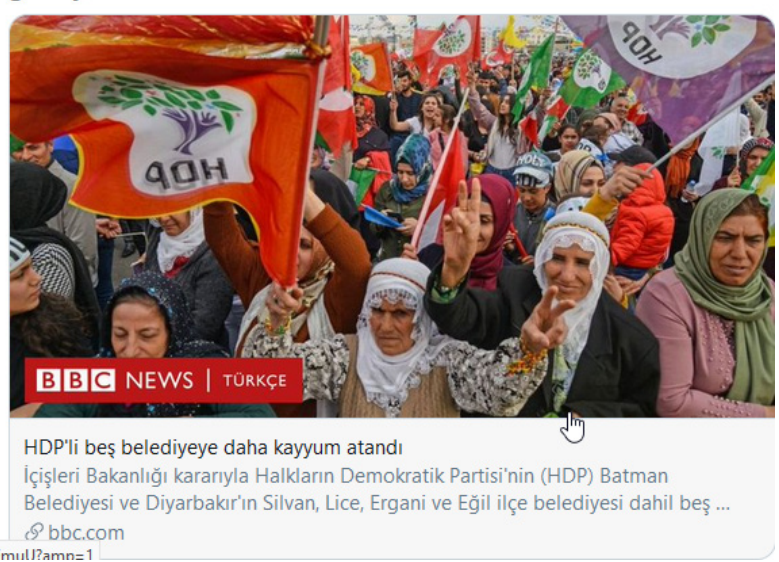

Görsel 2. BBC Türkçe'nin Eleştiri İşlevine Hizmet Eden Twitter Paylaşımları: BBC Türkçe, 30 Mart 2020 ve BBC Türkçe, 23 Mart 2020

Independent Turkish @Turkishlnd

Gelecek Partisi Genel Başkanı Ahmet Davutoğlu:

Türkiye'de işler yanlış gidiyor, yanlış yönetiliyor

Şimdiye kadar atılan adımlar gecikmeli atılmıştır

Süreli ve sınırlı sokağa çıkma yasağında tereddüt edilmemeli

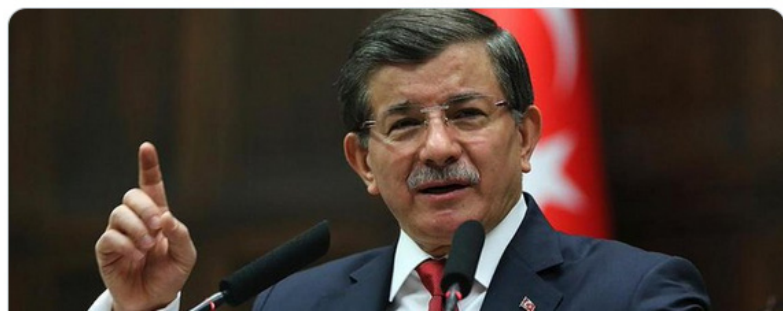

Görsel 3. Independent Türkçe’nin Eleștiri İşlevine Hizmet Eden Twitter Paylaşımları
Independent Turkish

@Turkishlndy

Türkiye'de vaka sayısı arttıkça vatandaş hastanelere başvuruyor

Koronavirüs testi yaptırmak isteyenler kuyruk oluşturdu

Dr. Sadi Konuk Eğitim ve Araştırma Hastanesi'nde test yaptırmak isteyenlerin oluşturduğu kuyruk havadan görüntülendi

independentturkish.com/node/152516

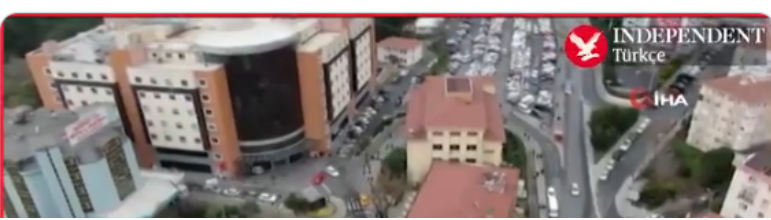

\section{6. Çerçeve}

$\mathrm{Bu}$ çalışmada her bir paylaşımın konuyu hangi tematik çerçeveden ele aldığı dört baskın çerçeve kullanılarak kodlandı: ekonomi, siyaset, sağlık ve kamu. Tüm hesaplarda COVID-19 ile ilgili paylaşımların konunun ele alınış çerçevesine göre dağılımı Şekil 8'de gösterilmektedir. 


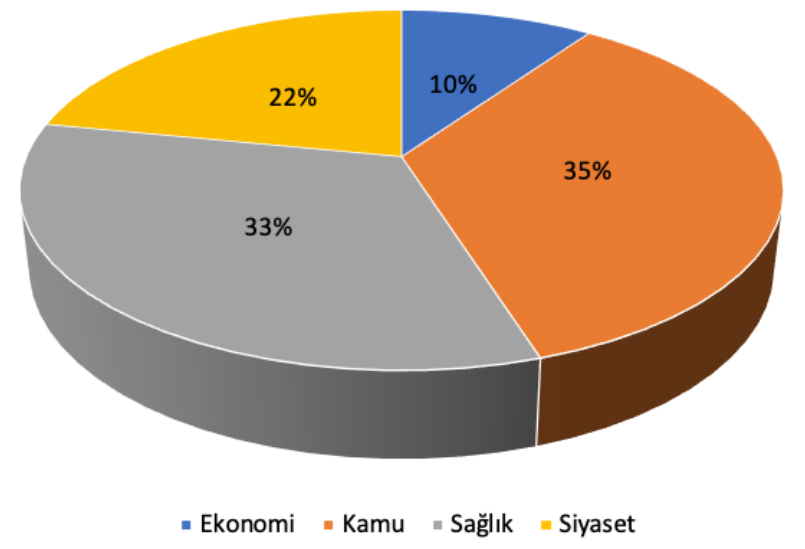

Şekil 8. Paylaşımların tematik çerçeveye göre dağılımı

Şekil 8'de gösterilen dağılıma göre paylaşımlar ağırlıklı olarak sağlık (\%33) ve kamu (\%35) tematik çerçevelerinden yapılmaktadır. Yani COVID-19 ile ilgili alınan kararlar, uygulanan tedbirler ve bireylerin ve toplumun sağlığı ile ilgili konular bu paylaşımların önemli bir kısmını olușturmaktadır. Bununla beraber incelenen hesapların tüm paylaşımlarının \%22'si siyaset ve \%10'u ekonomi çerçevesinden yapılmaktadır.

Paylaşımların tematik çerçevesinin hesaplara göre dağılımı Şekil 9'da gösterilmektedir. Buna göre BBC Türkçe ve DW Türkçe hesaplarında benzer bir dağılım izlenirken Independent Türkçe'nin her ikisinden de farklılaştığı görülmektedir. BBC Türkçe ve DW Türkçe'de en yoğun kamu çerçevesi işlenmiş, bunu sırasıyla sağlık, siyaset ve ekonomi takip etmiştir. BBC Türkçe paylaşımlarının \%34'ü kamu, \%31'i sağlık, \%27'si siyaset ve \%8'i ekonomi temalıdır. DW Türkçe'nin paylaşımlarının da benzer şekilde \%36'sı kamu, \%27'si sağlık, \%23'ü siyaset ve \%14'ü ekonomi çerçevelerinden yapılmıştır. Independent Türkçe'de ise paylaşımların tematik olarak en sık \%40 oranı ile sağlık çerçevesinden yapıldığı görülmektedir. Bu oranı sonrasında \%36 ile kamu, \%15 ile siyaset ve \%9 ile ekonomi izlemektedir.

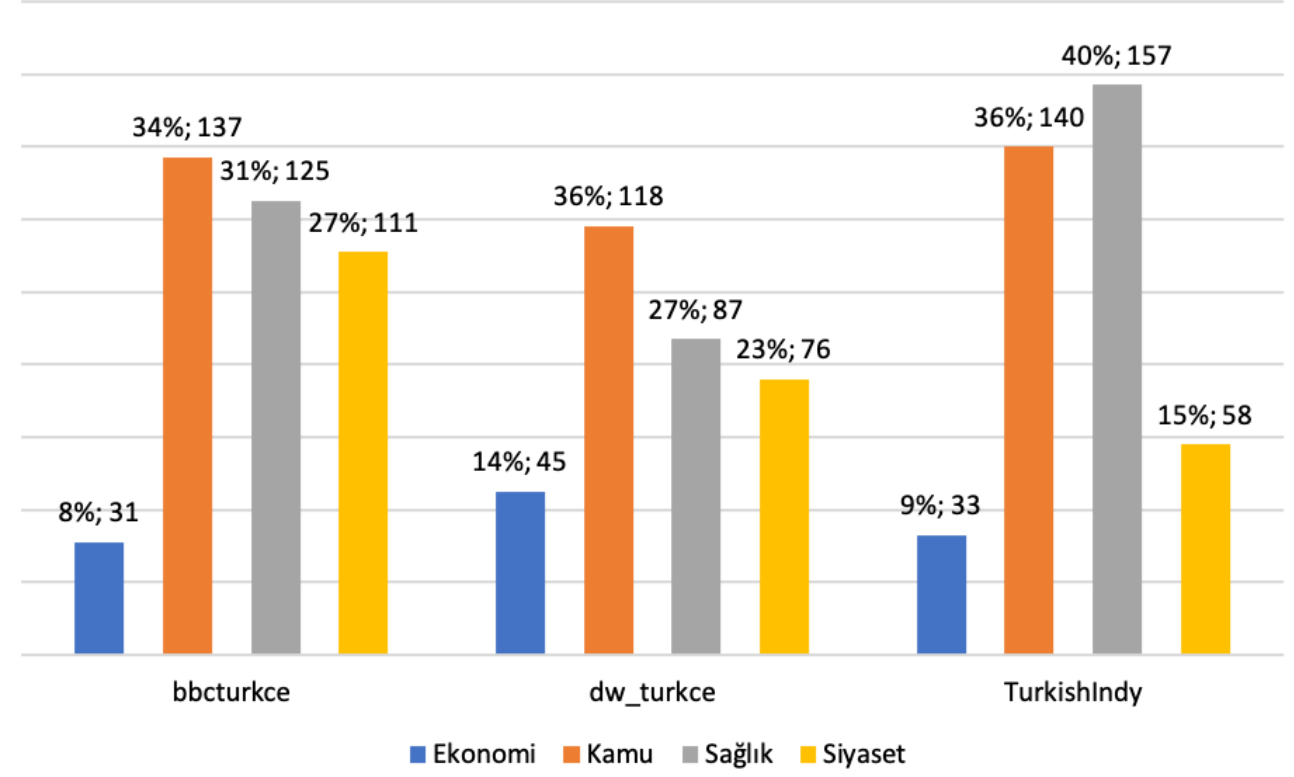

Şekil 9. Tematik Çerçevelerin Hesaplara Göre Dağılımı 


\subsection{Risk Algısı}

Batı Nil Virüsü salgınında risk iletişimini inceleyen Covello ve ark. (2001) kriz dönemlerinde korku, güvensizlik ve öfke gibi güçlü olumsuz duyguların etkili iletişime engel olduğunu hatırlatmaktadır. Nitekim COVID-19 gibi yüksek düzeyde belirsizliğin ve endișenin hakim olduğu uluslararası sağlık krizlerinde sosyal medyada dolaşan yanıltıcı haberler (dezenformasyon) sağlıklı bir kriz iletişiminin önündeki engellerin başında gelmektedir. Bu durumlarda risk iletişimi belirsizliği kabul ederek ve güven inşa ederek topluma değer kazandırabilir (Palenchar and Heath 2007) ve kurumların halkla ilişkilerine topluma önemli mesajları ulaştırmada ve olumsuz duygularla baş edebilmede ciddi anlamda destek olabilmektedir. Bu çalışmada COVID-19 paylaşımları 6 risk algısı etkeni ile kodlanmış, herhangi bir risk algısına rastlanmayan paylaşımlar boş (N/A) bırakılmıștır. Buna göre risk algısı etkenlerinin tüm hesaplara göre dağılımı aşağıdaki figürde yer almaktadır.

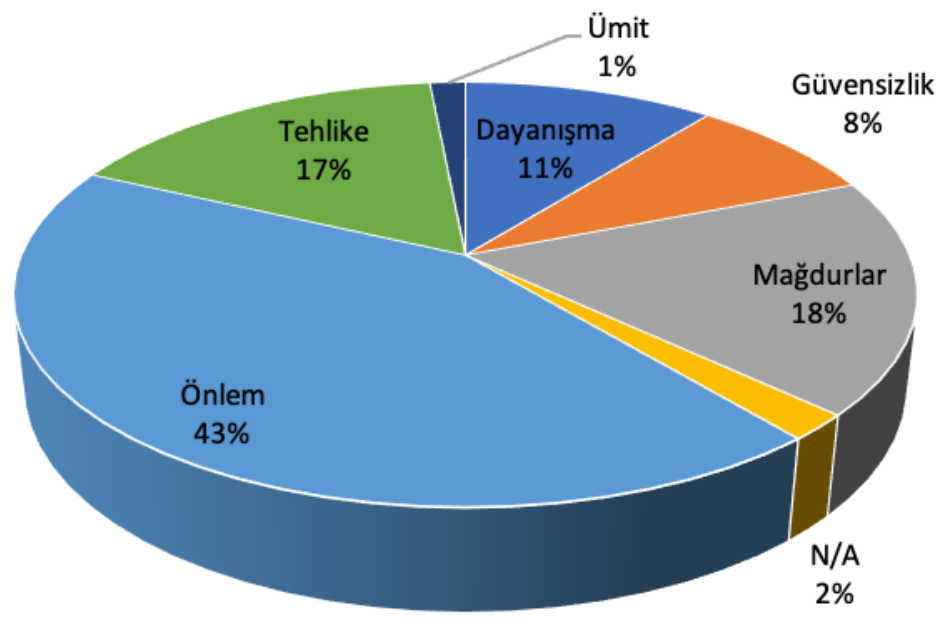

- Dayanışma = Güvensizlik = Mağdurlar = N/A = Önlem = Tehlike - Ümit

Şekil 10. Risk Algısı Etkenlerinin Tüm Hesaplara Göre Dağılımı

Buna göre paylaşımlarda en fazla öne çıkan risk algısı etmeninin \%43 ile "önlem" olduğu anlaşılmaktadır. Toplumla ya da kişilerle ilgili alınan tedbirleri ilgilendiren paylaşımlar önlem kategorisinde değerlendirilmiştir. Sonrasında ise en yüksek oran \%18 ile "mağdurlar" kategorisine aittir. Benzer biçimde risk algısı ile ilgili olarak tehlike (\%17) ve güvensizlik (\%8) kategorilerinin de yüksek oranda olduğu görülmektedir. Tüm mesajların yalnızca \%11'i dayanışma mesajı iletirken \%2'si nötr olarak kabul edilmiştir. Tüm bunlara mukabil risk algısı etmenleri açısından en düşük oran \%1 ile ümit kategorisindedir. $\mathrm{Bu}$ açıdan bakıldığında pandemi döneminde kriz iletişimi açısından büyük önem arz eden toplumsal direnci güçlendirecek içeriklerin üretimi oldukça düşük seviyelerde gerçekleşmiştir. Şekil 10'da görülebileceği üzere oransal açıdan güvensizlik ve tehlike kategorilerinin dayanışma ve ümit gibi olumlu mesaj ileten kategorilerden fazla olması dikkate değerdir. Nitekim etkileşim skorunun diğer analitik kategorilerle arasındaki ilişkiye yakından bakıldığında, risk algısı etkenleri açısından en yüksek etkileşim skoruna sahip paylaşımın "tehlike" algısı olduğundan daha önce bahsedilmişti. Aşağıda risk algısı etkeni "önlem” olarak kodlanan örnek paylaşımlar görülebilir:

- BBC Türkçe: İstanbul'da taksi plakası kısıtlaması bugün başladı. https://t.co/zXDvjHadx8 https://t.co/JLGsx5cbRv 
- Independent Türkçe: Adalet Bakanı Gül: Adliyelerde ve noterlerde nöbet sistemine geçildi. https://twitter.com/TurkishIndy/status/1242216301705248771

- DW Türkçe: "Koronavirüs salgınına karşı getirilen sokağa çıkma kısıtlamaları İstanbul'da: toplu taşıma kullanımını \% 82,7 azaldı. https://t.co/WkAEECjEvq"

Risk algısının ikinci sırasında ise günlük vaka sayıları, yaşamını yitirenlerle ya da hastalığa yakalananlarla ilgili paylaşımları içeren "mağdurlar" bulunmaktadır. Hesapların ilgili risk algısını taşıyan örnek paylaşımları aşağıda yer almaktadır:

- BBC Türkçe: COVID-19 tedavisi için hastanede bulunan Fatih Terim taburcu edildi. https://t.co/Owuc1gp1vc https://t.co/Fpppl5g8eY

- Independent Türkçe: Sağlık Bakanı Koca, Bilim Kurulu üyelerinden birinin koronavirüs testinin pozitif çıktığını açıkladı. https://twitter.com/TurkishIndy/ status/1246119515429232640

- DW Türkçe: “Türkiye'de ilk kez \#koronavirüs salgını nedeniyle bir kişi hayatını kaybetti Ülkedeki vaka sayısı da 47'den 98'e yükseldi... https://t.co/Mu5SEpJWOv"

Üçüncü sırada yer alan "tehlike" etkeni ise mağdurlarla oldukça yakın bir orana sahiptir. Salgının neden olduğu korku, endișe, tehdit ve tehlike içeren duygularla ilgili paylaşımlar "tehlike" risk algısı olarak kodlanmıştır. Bunların örnekleri ise şu şekildedir:

- BBC Türkçe: Koronavirüs: Hekimler ve sağlı görevlileri güvenli koşullarda çalışabiliyor mu? https://t.co/e7V78NF2RG"

- Independent Türkçe: Başak Demirtaş: "Personeliyle, tutuklusuyla cezaevindeki insanlar koronaya terk edilmiş durumda" https://twitter.com/TurkishIndy/ status/1240422242753736704

- DW Türkçe: "163 milyar lira bütçe açığı olan Türkiye bu krize hazırlıksız yakalandı" https://t.co/LREVvUfA55"

Dördüncü olarak ise salgının etkilerini hafifletmek için gösterilen yardımlaşmaya dair paylaşımların yer aldığı "dayanışma" gelmektedir. Hem Türkiye'nin başka ülkelerle olan dayanışma adımlarını hem de Türkiye'de gerçekleşen dayanışma ve süreci kolaylaştırma faaliyetlerini içeren paylaşımlar bu başlık altında kodlanmıştır. İlgili örnekler aşağıdaki gibidir:

- BBC Türkçe: İstanbul Valiliği maddi durumu iyi olmayan 65 yaş ve üstü vatandaşlara ulaştırılacak 50 bin gıda kolisinin yola çıktığını açıkladı. https://t.co/MEWLFOlUOT

- Independent Türkçe: BDDK'dan koronavirüs kararı: Kredi ödemelerindeki gecikmelere esneklik tanınacak.

https://twitter.com/TurkishIndy/status/1239958053098840073

- DW Türkçe: Türkiye, Libya'ya ve bölgede görev yapan Türk eğitim, iş birliği ve danışma timlerine de sağlık malzemesi gönderdiğini açıkladı. https://t.co/oYpEIUgnSQ

Sorumlu kurumların ya da kişilerin salgınla ilgili açıklama ve icraatlarına duyulan güvensizliği konu edinilen paylaşımlar "güvensizlik" risk algısı etmeni olarak kabul edilmiştir. Risk algısı sıralamasında beşinci sırada yer alan "güvensizlik" kategorisine ait örneklere aşağıda yer verilmiştir:

- BBC Türkçe: TTB: Açıklanan COVID-19 vaka sayıları ve ölüm sayıları arasında paralellik yok. https://t.co/tAWbLZQ2F8 https://t.co/wEoCiFAekK 
- Independent Türkçe: Kadın Dernekleri Federasyonu Başkanı Güllü'den infaz düzenlemesi tepkisi: Siyasi tweet atan çlkamayacak, karısının yüzüne kezzap atan çıkacak https://twitter.com/TurkishIndy/status/1247288221790130176

- DW Türkçe: “Dünya Sağlı Örgütü'nün tavsiyesi Türkiye'de hiçe sayıldı"”

- Hükümetin koronavirüsle mücadelede ikinci bilim kuruluna da sağlı meslek örgütlerinden temsilci almaması tartışmalara yol açtı. https://t.co/8wCuXaE39W"

6. sırada ise herhangi bir risk algısına rastlanmayan "Nötr" paylaşımlar bulunmaktadır. Bunu arada küçük bir farkla "ümit" kategorisi takip etmektedir. İlgili "ümit" içerikli paylaşım örnekleri şu şekildedir;

- BBC Türkçe: Sağlık Bakanı Fahrettin Koca: 60 yaş üzeri iki hasta iyileşerek taburcu oldu https://bbc.in/2y8N6dS

- Independent Türkçe: İnönü Üniversitesi'ndeki plazma tedavisinde olumlu sonuç: Kovid-19 hastasında iyileșme görüldü. https://twitter.com/TurkishIndy/ status/1248556645212356608

- DW Türkçe: “Türkiye'de salgının hızının Mayıs sonu gibi azalacağı ümidimiz var ama kesin yargıda bulunmak mümkün değil" https://t.co/lWQfF9GwuQ"

Hesaplara göre risk algısı etkenlerinin dağılımı ise aşağıdaki figürde gösterilmektedir.

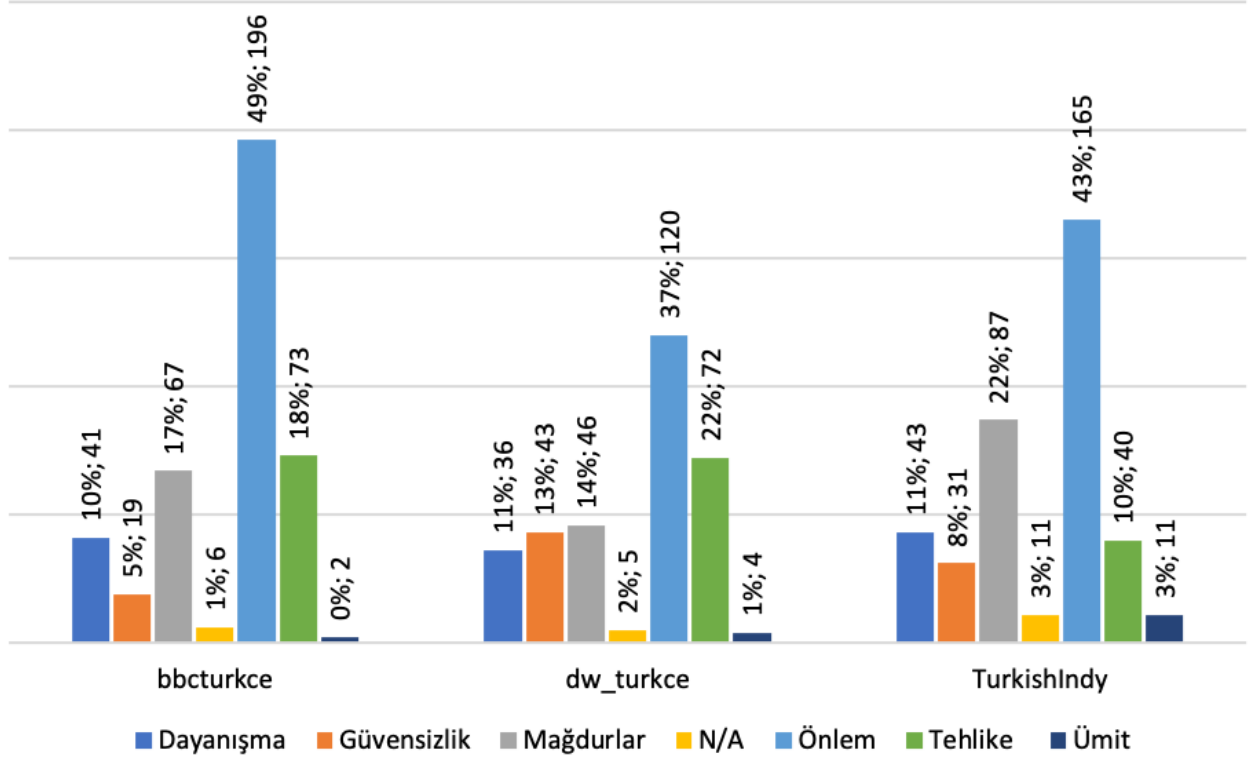

Şekil 11. Risk algısı etkenlerinin hesaplara göre dağılımı

Bu çalışmada belirlenen risk algısı etkenleri küresel bir salgın sağlık sorununda ortaya çıkabilecek etkenlerdir. Bu bağlamda önlem ve mağdurlar ile ilgili etkenlerin fazlalığı olağanken, tehlike ve güvensizlik risk etkenlerinin mevcut krizi daha da derinleștirdiği söylenebilir. Bu bağlamda, çalışmanın devamında güvensizlik ve tehlike risk algılarını içeren her bir hesaptaki örnekler, kriz iletişimi açısından önem arz etmekte ve nelerin yapıl(ma)ması gerektiğine dair de ipuçları vermektedir.

Şekil 11'e göre BBC Türkçe \%49 oranı ile en fazla “önlem” risk algısı içeren paylaşımlara yer vermiștir. Bunu ikinci sırada \%18 ile "tehlike" risk algısı takip etmiștir. \%17 oranı ile üçüncü sırada yer alan "mağdurlar" risk temasını sırasıyla dayanışma (\%10), güvensizlik (\%5), nötr $(\% 1)$ ve ümit $(\% 0,49)$ takip etmektedir. Açıkça görülmektedir ki tehlike ve 
güvensizlik gibi olumsuzluk içeren risk algısı etkenleri olumlularla dengelenmemektedir. Hatta örneklerde olduğu gibi önlem ve mağdurlar risk algısını içeren kimi paylaşımların da olumsuz mesajlar ilettiği hesaba katıldığında olumlu mesaj ileten risk algısı etkenlerinin oranının oldukça düşük olduğu söylenebilir.

BBBd BBC News Türkçe

@bbcturkce

TTB: Açılanan COVID-19 vaka sayıları ve ölüm sayıları arasında paralellik yok bbc.in/2JLq1jU

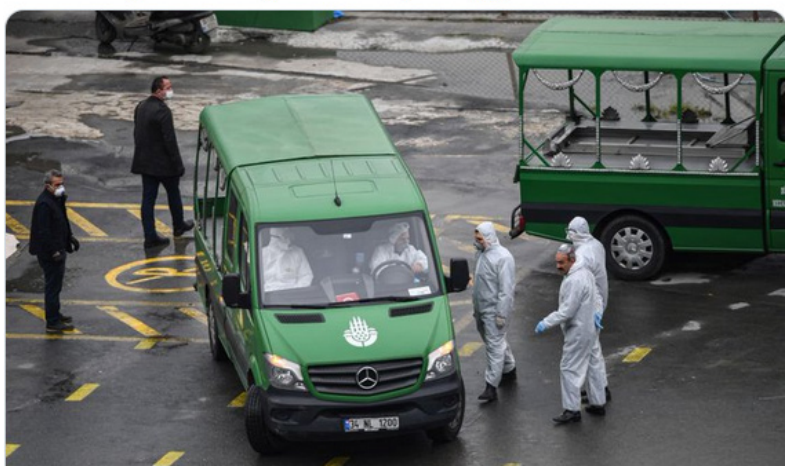

BBC News Türkçe @bbcturkce· 10 Nis

Türkiye'de \#koronavirüs hastalarına bakan yoğun bakım doktorları neler yaşıyor?

"Hasta sayımız artınca depodan 1980, 1985, 1990 yapım, ekranı bile olmayan, manuel çevirmeli solunum cihazları çıkardık, hangileri çalışıyorsa onları kullanıyoruz."

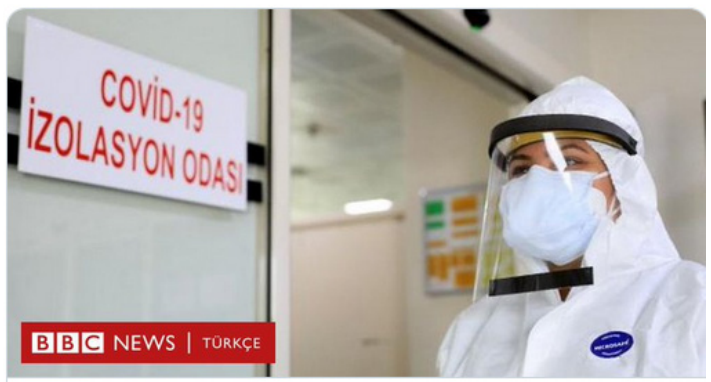

Türkiye'de yoğun bakım doktorları koronavirüs salgını sırasında neler ya... Ankara, İzmir ve İstanbul'daki büyük kamu hastanelerinde görev yapan üç yoğun bakım uzmanı koronavirüs salgınıyla beraber neler yaşadıklarını ... $\mathcal{S}$ bbc.com

Görsel 4. BBC Türkçe'nin Güvensizlik ve Tehlike Risk Algılarına Dair Örnekleri: BBC Türkçe, 8 Nisan 2020 ve BBC Türkçe, 10 Nisan 2020

DW Türkçe'de de benzer bir sıralama olduğu görülmektedir. İlk sırada \%37 oranı ile büyük farkla önlem yer almış, bunu sırasıyla \%22 ile tehlike, \%14 ile mağdurlar, \%13 ile güvensizlik, \%11 ile dayanıșma, \%2 ile nötr ve \%1 ile ümit takip etmiștir. Güvensizlik risk algısının en yoğun görüldüğü hesap DW Türkçe olmuştur. Küresel salgın gibi ciddi bir krizde, krizin derinleşmesine neden olacak "güvensizlik" algısının bu denli ön plana çıkartılması ise dikkate değerdir.

DW Türkçe @ @dw_turkce.8 Nis

Sağlık Bakanlığı́nın Covid-19 ölümlerini DSÖ'nün önerilerine göre raporlamadığını savunan Türk Tabipleri Birliği'ne göre, Türkiye'de bazı koronavirüs kayıpları "doğal ölüm" olarak kayda geçiriliyor

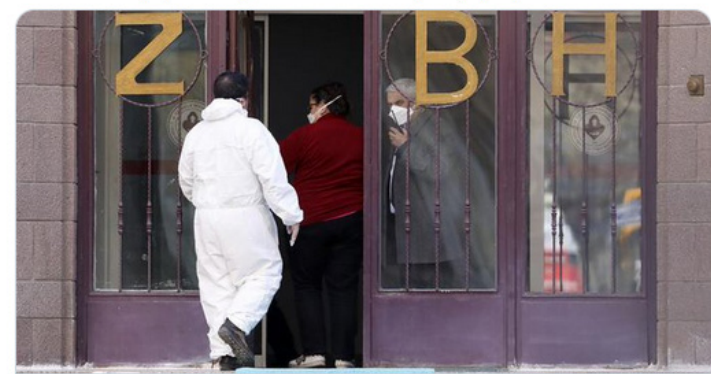

TTB: Bakanlık korona ölümlerini doğru raporlamıyor Sağlık Bakanlı̆̆ı́nın Covid-19 ölümlerini Dünya Sağlık Örgütü'nün önerilerine göre raporlamadığını savunan Türk Tabipleri Birliği, bazı .. $\mathcal{O}$ dw.com

"Kirli bilgi ortamından istifadeyle internetin tamamen kontrol altına alınabileceği bir Türkiye'ye doğru hızla ilerliyoruz. Totaliter rejim kendini açıkça gösteriyor"

Koronayla mücadele kapsamındaki yasa paketine sosyal medyanın da eklenmesi eleștiriliyor

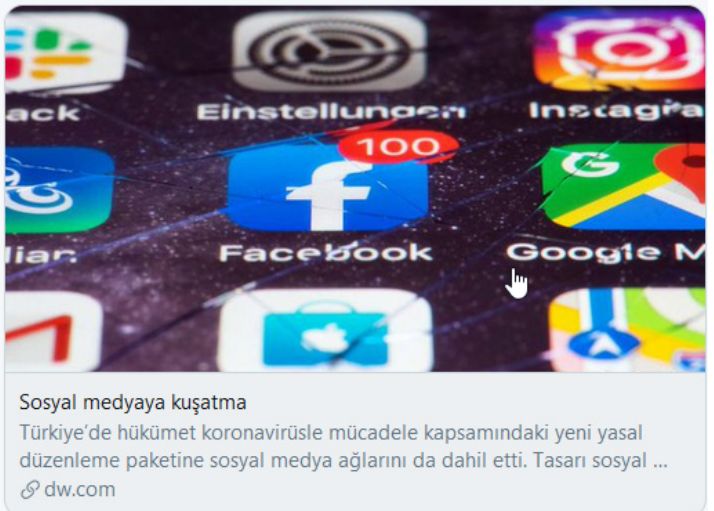

Görsel 5. DW Türkçe'nin Güvensizlik ve Tehlike Risk Algılarına Dair Örnekleri: DW Türkçe, 8 Nisan 2020 ve DW Türkçe, 9 Nisan 2020

Independent Türkçe'nin paylaşımlarının diğer iki yayın organına göre farklılık gösterdiği risk algısı temalarındaki sıralamadan anlaşılmaktadır. Diğer hesaplarda olduğu gibi birinciliğin \%43 oranı ile "önlem" algısına ait olduğu listede sırasıyla \%22 ile mağdurlar, \%11 ile dayanışma, \%10 ile tehlike, \%8 ile güvensizlik ve \%3 ile eşit oranlarla nötr ve ümit 
algılarını içeren paylaşımlar takip etmektedir. Salgın bir hastalık durumu ile ilgili yapılan paylaşımların önlem, sağlık ve dayanışma algıları etrafında yoğunlaşması Independent Türkçe'yi incelenen diğer hesaplardan ayrıştırmaktadır. Buna mukabil, güvensizlik ve tehlike gibi kategorilerde Independent Türkçe'yi diğer iki hesaptan ayıran bir husus, her iki risk algısının muhalif parti liderleri tarafından yapılan açıklamalar ile şekillenmiş olmasıdır. Pandemi süreci ile ilgili alınan önemlerin, eleştirilmesinin gerekliliği bir yana devamlı surette yeni bir öneri ile muhalefet edilmesi ve bu açıklamaların bu hesapta daha fazla ön plana alınması dikkat çekmektedir.

Independent Turkish

@Turkishlndy

ÖZEL HABER | Bakanlık 28 Mart'ta 16 ölüm duyurdu, aynı tarihte e-Devlet'teki veriye göre İstanbul'da koronavirüsten ölen sayısı 20

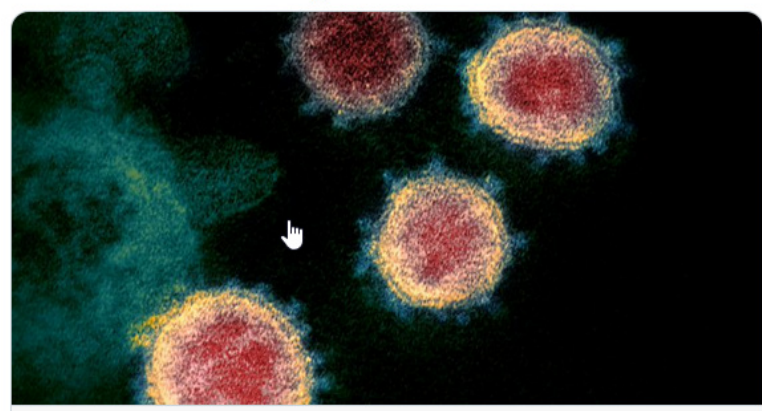

Bakanlık 28 Mart'ta 16 ölüm duyurdu, aynı tarihte e-Devlet'tek Çin'de ortaya çııan ve Türkiye'de de etkisini gösteren koronavirüs nedeniyle 11

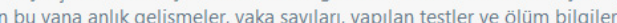

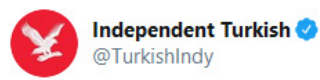

Türkiye'deki koronavirüs salgınında 3 farklı senaryo: Haziran sonunda vaka sayısı 3,5 milyonu aşabilir

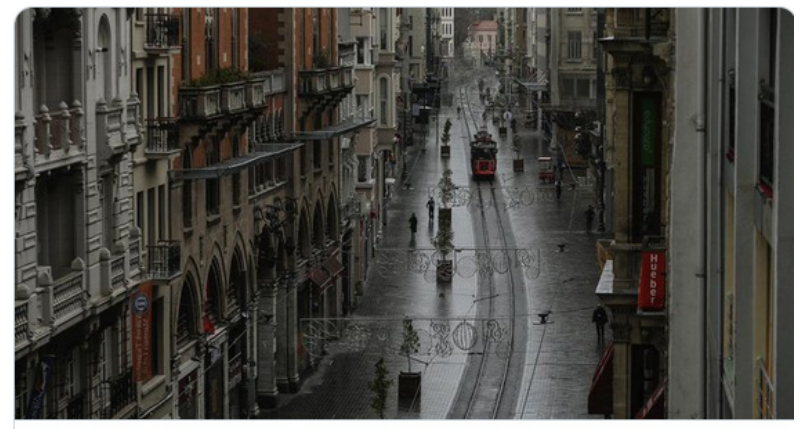

Türkiye'deki koronavirüs salgınında 3 farklı senaryo: Haziran sonunda Türkiye'de yeni tip koronavirüs (Kovid-19) salgının hızla yayılmasıyla vaka ve ölü sayıları da artış gösteriyor. Türkiye'de ilk koronavirüs vakanın açıklandığı 11 Mart ... $\mathcal{P}$ indyturkish.com

Görsel 6. Independent Türkçe'nin Güvensizlik ve Tehlike Risk Algılarına Dair Örnekleri: Independent Türkçe, 29 Mart 2020 ve Independent Türkçe, 26 Mart 2020

COVID-19 salgını ile alınan ve uygulanan tedbirlerle ilgili olan önlem risk algısı etkeninin en sık olması ve dayanışma etkeninin de tüm hesaplardaki birbirine yakın dağılımı olumlu bir bulgudur. Ancak tehlike ve güvensizlik algı etkenlerinin ümit etkenine baskınlı̆̆ı risk algısı iletişimi açısından dikkate değer bir olumsuzluk arz etmektedir. Risk bilgisinin nasıl işlendiğini, risk algılarının nasıl oluşturulduğunu ve risk kararlarının nasıl alındığını tanımlayan risk algısı modeline göre risk algısının pek çok duygu tarafından belirlendiğine ve bunların risk algı derecesini değiştirdiğine inanılmaktadır (Covello, Peters, \& Wojtecki, 2001; Slovic, 1987; Rogers, 1997; Wildavsky \& Dake, 1990; Renn, Bums, Kasperson, Kasperson, \& Slovic, 1992). Buna göre korku, endişe ve terör duygularını uyandıran riskler, uyandırmayanlara göre daha büyük olarak algılanmaktadır (Covello, Peters, \& Wojtecki, 2001). Bu duygular, riske dair algıların öznel değerlendirmesine yol açarken bireylerin davranışlarını ve söz konusu tehdide verdikleri cevapları da belirlemektedir (Guidry, Jin, Caroline, Messner, \& Meganck, 2017). Etkileşim kategorisinde en yüksek etkileşim skoruna sahip paylaşımların 'tehlike' risk algısı etkenini içerdiğini söylemiştik. 'Güvensizlik' etkeni içeren paylaşımlarla birlikle ele alındığında 'tehlike' algısının etkileşimin daha yüksek çıkacağı ortadadır. Bu iki etkenin risk iletişiminde sağlıklı bilgi işleme ve bununla ilgili karar alma sürecine de tesir ettiği ilgili literatürde yer almaktadır. Zira Güven Belirleme Modeline göre kriz durumlarında etkili iletişimin başarısı güven duygusuna bağlıdır, güven duygusunun tesis edilmesi önemli bilginin işlenmesi ve hatırda tutulması ve dolayısıyla tavsiye edilen eylemlerin gerçekleştirilmesi için elzemdir (Covello, Peters, \& Wojtecki, 2001; Reynolds, 2009). 


\section{Sonuç}

COVID-19 pandemisi, 2020 yılının Mart ayında ilk vakanın görülmesiyle birlikte Türkiye'yi etkisi altına almıș ve kısa sürede tüm gündemi belirleyen bir konu olmuștur. Süreç içerisinde vaka sayısındaki yaşanan nispi artış ve hastalığın tedavisinin belirsizliği, şüphesiz toplumda bir korku ve panik havasının doğmasına neden olmuştur. İngiltere'nin sürecin başında hastalığa karşı doğal bağıșıklık yolunu tercih ederek vatandaşlarını korumaya yönelik bir adım atmaması, İtalya ve İspanya'da sağlık alt yapısı ve tedbirlerin yetersizliği nedeniyle ölüm oranlarının oldukça yüksek olması, ABD'nin önlemler konusundaki gevşek tavrı ve sağlık hizmetlerindeki aksaklıklar bu kaygıların temelini oluşturmuştur.

Türkiye ise tüm bu olumsuz örneklerin aksine sürecin başından itibaren salgınla en etkin ve başarılı mücadele eden ülkelerden biri olmuştur. Gerekli önlemlerin zamanında alınması, sağlık sisteminin başarılı bir şekilde işlemesi, devletin süreci kolaylaştırmaya yönelik ekonomi ve kamu politikalarının yanı sıra süreç içerisinde uygulanan kriz iletişimi ile salgın önemli ölçüde kontrol altına alınmıștır. Birçok ülke ile karşılaștırıldığında daha başarılı yürütülen bu süreç farklı yabancı medya organlarının Türkçe servislerinde olduğu gibi yer almamıştır. Bu makale, DW Türkçe, BBC Türkçe ve Independent Türkçe'nin 15 Mart-10 Nisan 2020 tarihleri arasında Türkiye'de koronavirüs ile ilgili Twitter paylaşımlarının analizini sunmakta ve verilere dayalı bir analiz içermektedir.

Öncelikle hesaplardan paylaşılan tweetlerin \%61 gibi büyük bir kısmının toplumla ilgili olduğu tespit edilmiştir. Kurumlarla ilgili toplam paylaşım \%39 olmasına rağmen bu paylaşımları oluşturan toplam 432 tweetin 149'u eleştiri ve yalnızca 33 tanesi övgü içermektedir. İşlev olarak bakıldığında da üç mecra için incelenen tüm tweetlerin \%74'ü bilgi verirken \%21'i eleştiri ve \%5'i övgü içeren paylaşımlara yer vermiștir. Eleştirinin en yüksek olduğu mecra ise DW Türkçe (\%33) olarak tespit edilmiștir. Her üç mecra da hükümeti ekonomi, siyaset ve sağlık politikaları ekseninde eleştiren paylaşımlara yer vermiştir. Genel olarak süreçle ilgili hükümeti vaka ve ölüm sayılarında şeffaf davranmama, güvenilir bir bilim kurulu oluşturmama, infaz yasası düzenlemesinde adil davranmama, belediyelerin yardım toplamasına engel getirildiği iddiaları ve pandemi süreci bahane edilerek WhatsApp, Youtube gibi internet araçlarının denetimi noktasında otoriter bir eğilim geliştirme gibi konu ve iddialar üzerinden eleștirmişlerdir. BBC Türkçe'de sağlık personellerinin olumsuz koşullarda çalıștığı ve salgının boyutunun oldukça yüksek olduğu gibi kötümser senaryolarla birlikte hükümetin ekonomi politikalarına ve işçilerin çalışma koşullarına dair eleştiriler ön plana çlkarken, DW Türkçe salgın döneminde hapishanelerin durumu ve infaz yasası düzenlemesinin siyasi suçlulara uygulanmaması noktasında eleştirilere ağırlık vermiştir. Ayrıca sağlık politikalarında yanlışlıklar ve geç alınan kararlar olduğu iddialarını da eleştirel bakış açıları ile derinleştirmiştir. Eleştirinin en düşük olduğu Independent Türkçe, sık sık farklı siyasi figürlerin hükümete yönelik eleştirilerini gündeme getirmiştir. Haberlerin kapsamı daha çok Türkiye'nin bu süreci yönetmek için ne gibi tedbirler aldığı ve ne tür çalışmalar yaptığı yönünde olmuştur. Genel tabloda dikkat çeken nokta cezaevlerindeki durum ve infaz yasası üzerinde çok durulduğu ve HDP'li siyasetçilerin söylemlerinin öne çıkarılması olmuştur. Zaman zaman Babacan ve Davutoğlu'nun süreç ile ilgili eleştirel açıklamalarına da (hükümetin aldığı kararların yanlış ve yetersiz olduğu) yer veren Independent Türkçe, bu yönüyle BBC Türkçe ve Deutsche Welle'den ayrışmıştır.

Mecraların paylaşımlarında öne çıkan bir diğer hususa risk algısı kategorisinde rastlanmıştır. Kodlama için belirlenen toplam 7 farklı risk algısı seçeneğinden "tehlike" 
ve "güvensizlik" gibi olumsuz duygu ve davranışlara neden olabilecek risk algısına hizmet eden içeriklerin oranı dikkat çekmektedir. Risk algısında en fazla içerik \%43 oranı ile "önlem" ve sonrasında \%18 ile "mağdurlar" olarak kodlanmışken bunu sırasıyla tehlike (\%17), dayanışma (\%11) ve güvensizlik (\%8) takip etmiştir. Ümit veren (\%1) ve nötr (\%2) olan tweetlerin sayısı ise oldukça düşük bir seviyede kalmıştır. Toplamda kodlanan 1118 tweetin 481 tanesi önlem, 200 tanesi mağdurlar, 185'i tehlike, 120'si dayanışma, 93'ü güvensizlik, 22 tanesi nötr ve 17'si ümit olarak kodlanmıştır. Yukarıda da ifade edildiği gibi en fazla etkileşim alan tweetler içerisinde güvensizlik ve tehlike kategorilerinin varlığı dikkat çekmektedir. Mecraların ayrı ayrı risk analizlerine bakıldığında en fazla güvensizlik (\%13) ve tehlike (\%22) içeren paylaşımın DW Türkçe'ye ait olduğu belirlenmiştir. BBC Türkçe \%18 oranı ile tehlike mesajı içeren paylaşımlara ikinci sırada en fazla yer veren mecra olmuşken bunu \%10 ile Independent Türkçe takip etmiştir. Güvensizlik kategorisinde en fazla tweete yer veren DW Türkçe’yi \%8 ile Independent Türkçe ve \%5 ile BBC Türkçe takip etmiştir.

Mecraların ayrı ayrı risk algısı karşılaştırmasında göze çarpan örneklere bakıldı̆̆ında BBC Türkçe'nin Türk Tabipler Birliği açıklamaları ışığında vaka sayılarının açıklanandan yüksek olduğuna dair güvensizlik algısını işlediği görülmektedir. Ayrıca kimliği belirsiz doktorlarla yapılan röportajlarla yoğun bakım servislerinde ekipman sorunun olduğu ve servislerin hasta yoğunluğunu kaldıramadığı gibi tehlike hissi uyandıracak paylaşımlara da rastlanmaktadır. DW Türkçe de BBC Türkçe ile benzer tehlike, korku ve güvensizlik temalarını haberleştirmiștir. Sağlık Bakanlığı verilerine dair güvensizlik içeren mesajların paylaşımı şeffaflık eleştirisi ve internet kullanımına doğrudan bir devlet müdahalesi ile otoriterliğin artacağı iddiaları mecranın ana tehlike ve güvensizlik temalarını oluşturmaktadır. Tehlike ve güvensizliğe dair risk algısı ise karşılaştırmalı olarak bakıldığında en düşük Independent Türkçe'de görülmüştür. Buna mukabil sık sık HDP, İyi Parti, CHP, Gelecek Partisi ve DEVA Partisi başkanlarının eleştirilerini paylaşan mecra, yayınladığı özel haberlerle vaka sayılarında tutarsızlık olduğu yönündeki iddialar ile güvensizlik uyandıracak mesajları takipçilerine iletmiştir. Resmî duyuruları ve önlemleri iletmenin yanı sıra özellikle "Koronavirüse karşı mücadeleyi en ön cephede veren hekimler tükenmek üzere: Aynı hekim hem normal hastaya hem koronavirüslü hastaya bakıyor" gibi "özel haber" statüsündeki içerikler ile de oldukça karamsar bir tablo çizmiştir.

Nihayetinde güvensizlik ve tehlike tweetleri süreç içerisinde krizi yöneten yetkililerin açıklamaları ile ters düşen ve yetkililerin açıklamalarını kamusal düzlemde tartışılır kılan açıklamalardır. Bu tip içeriklerin üretilmesi ve sosyal medyada dolaşıma sokularak ciddi etkileşim yaratılması, kriz iletişimi ve süreç yönetimi açısından risk barındırmaktadır. Yapıcı eleştirilerde bulunmak ve aksaklıkların düzeltilmesi için mevcut sorunlara eğilmek basın-yayın araçlarının görevlerindendir. Ancak pandemi gibi insan sağlığını ilgilendiren bir konuda küresel ölçekte ciddi olumsuzluklar yaşanırken, teyit edilmemiş iddialar ve spekülasyonlar üzerinden güvensizlik ve tehlike odaklı içeriklere ağırlık verilmesi, bilgi kirliliğine (infodemi) neden olmakta ve kriz anlarında toplum sağlığı için gerekli olan otoriteye güveni sarsmaktadır. 


\section{Kaynakça}

Alhabash, \& Mcalister. (2014). Redefining virality in less broad strokes: Predicting viral behavioral intentions from motivations and uses of Facebook and Twitter. New Media \& Society.

B. J. Reynolds. (2009). Building trust through social media. CDC's experience during the H1N1 influenza response. Marketing Health Services, , 18-21.

Bortree, \& Seltzer. (2009). Dialogic Strategies and Outcomes: An Analysis of Environmental Advocacy Groups' Facebook Profiles. Public Relations Review.

Covello. (1998). Risk perception, risk communication, and EMF exposure: Tools and techniques for communicating risk information. Risk perception, risk communication, and its application to EMF exposure: Proceedings of the world health organization/ICNRP International Conference (pp. 179-214). Vienna: Internatonal Commission on Non-Ionizing Radiation Protection.

Covello, \& McCallum and Pavlova. (1989). Principles and guidelines for improving risk communication. In Covello, McCallum, \& a. Pavlova, Effective Risk Communication: the Role and Responsibility of Government and Nongovernment Organizations (pp. 3-16). New York: Plenum Press.

Covello, \& Sandman. (2001). Risk communication: Evolution and revolution. In A. Wolbarst, Solutions to an Environment in Peril (pp. 164-178). Baltimore: John Hopkins University Press.

Covello, Peters, \& Wojtecki. (2001). Risk communication, the West Nile virus epidemic, and bioterrorism: responding to the commnication challenges posed by the intentional or unintentional release of a pathogen in an urban setting. J Urban Health, 382-391.

G.Cairns, Andrade, M. d., \& MacDonald, L. (2013). Reputation, relationships, risk communication, and the role of trust in the prevention and control of communicable disease: A review. Journal of Health Communication, 1550-1565.

Glik, D. C. (2007). Risk communication for public health emergencies. Annual Review of Public Health, 33-54.

Guidry, Jin, Y., Caroline, A. O., Messner, M., \& Meganck, S. (2017). Guidry, Yan Jin, A. Orr CarolinEbola on Instagram and Twitter: How health organizations address the health crisis in their social media engagement. Public Relations Review, 477-486.

Habermas, J. (2020). Dans cette crise, il nous faut agir dans le savoir explicite de notre non-savoir. Le Monde.

Hanioğlu, Ş. (2020). COVID-19 Sonrası küresel düzen: İki seçenek. In COVID-19 Sonrası Küresel Sistem: Eski Sorunlar, Yeni Trendler (pp. 24-28). Ankara: SAM Yayınları.

J.Baron, C.Hershey, J., \& Kunreuther, H. (2000). Determinants of priority for risk reduction: The role of worry". Risk Analysis, 413-428.

Kissenger, H. (2020). The coronavirus pandemic will forever alter the world order. Wall Street Journal.

Lovejoy, K., \& Saxton, G. D. (2012). Information, community, and action: How nonprofit organizations use social media. Journal of Computer-Mediated Communication, 337-353. 
Maslow, A. (1970). Motivation and personality. New York: Harper and Row.

McAllister, \& Spooner. (2009). Fulfilling the dialogic promise: A ten-year reflective survey of dialogic Internet principles. Public Relations Review, 320-322.

Neiger, B. L., Thackeray, Burton, Thackeray, \& Reese, \&. (2013). Use of Twitter among local health departments: An analysis of information sharing, engagement, and action. Journal of Medical Internet Research.

P. Slovic, “. e.-a. (1999). Trust, emotion, sex, politics, and science: surveying the riskassessment battlefield. Risk Anal,, 689-701.

Park, Reber, \& Chon. (2016). Tweeting as health communication: Health organizations' use of Twitter for health promotion and public engagement. Journal of Health Communication, 188-198.

Park, Rodgers, \& Stemmle. (2013). Analyzing health organizations' use of Twitter for promoting health literacy. Journal of Health Communication, 410-425.

Peters, R., Covello, V., \& McCallum, D. (1997). The determinants of trust and credibility in environmental risk communication: an empirical study. Risk Anal, 43-54.

Pew Research Center (2015). Social media update 2014. https://www.pewresearch.org/ internet/2015/01/09/social-media-update-2014/ Erişim tarihi: 24.04.2020

TranslateMEdia (2020). Turkey Social Media. Erişim adresi: https://www. translatemedia.com/translation-services/social-media/turkey-social-media/ Erişim tarihi: 24.04.2020

Renn, O., Bums, W., Kasperson, J., Kasperson, R., \& Slovic, P. (1992). The social amplification of risk: theoretical foundations and empirical applications. J Soc Sci Issues, 137-160.

Reynolds, B. J. (2009). Building trust through social media. CDC's experience during the H1N1 influenza response". Marketing Health Services, 18-21.

Rogers, G. (1997). The dynamics of risk perception: how does perceived risk respond to risk events. Risk Anal, 745-757.

Slovic, P. (1987). Perception of Risk. Science, 280-285.

Sommerfeldt, Kent, \& Taylor. (2012). Activist practitioner perspectives of website public relations: Why aren't activist websites fulfilling the dialogic promise? Public Relations Review, 303-312.

Veil, Buehner, \& Palenchar. (2011). A work-in-process literature review: Incorporating social media in risk and crisis communication .Journal of Contingencies and Crisis Management, , 110-122.

Wildavsky, A., \& Dake, K. (1990). Theories of risk perception: who fears what and why. Daedalus, 41-60. 


\title{
Content Analysis of Foreign Media Agencies' Social Media Shares in the Pandemic Process: BBC Turkish, DW Turkish, and Independent Turkish Examples
}

\author{
Turgay Yerlikaya (Asst. Prof. Dr.) \\ İbrahim Efe (Assoc. Prof. Dr.) \\ Kevser Hülya Akdemir (Ph.D. Student)
}

\section{Extended Abstract}

The COVID-19 pandemic has gripped life globally in 2020. This process, which countries aim to overcome with the least damage via an effort involving different strategies, has attracted the attention of global public opinion. Thanks to its swift response to the pandemic with early measures and a robust public policy Turkey, like Germany and Japan, has been successful in its fight against the disease. Undoubtedly, the unfolding of the pandemic, which concerns the whole society, has been at the center of media attention, both traditional and new, whose primary function of informing the public has been more significant during the process.

In this study, Twitter messages of Turkish accounts of the BBC, the Deutsche Welle, and the Independent between March 15 to April 10, 2020, on the coronavirus have been examined. The retrieved data were analyzed via content analysis and the findings were compared quantitatively and evaluated in terms of their role in risk communication.

First of all, it has been determined that $61 \%$ of the tweets shared from the accounts are related to society. The total of messages about institutions is 39\%, 149 of the 432 tweets that make up these posts contain 'criticism' and only 33 of them contain 'praise'. In terms of function, 74\% of all tweets examined through three accounts aims to give information, while $21 \%$ included comments containing criticism and 5\% praise. The account with the highest rate of 'criticism' content is DW Turkish (33\%). All three accounts feature posts criticizing the government in terms of economy, politics, and health policies. In general, they criticize the government related to the process, such as not being transparent as to the number of announced cases and deaths, not establishing a reliable scientific board, not acting fairly in the regulation of the executive law, allegations that the municipalities are prevented from collecting aid, and using the process as a pretext to establish an authoritarian approach to the control of internet tools such as Twitter, WhatsApp, and YouTube.

Another issue that stands out in the messages of the 3 accounts relates to the risk perception category. Among 7 different risk perception factors identified for coding, the rate of content serving the risk perception that causes negative emotions and behaviors such as "danger" and "insecurity" draws attention. The most frequently coded risk factor is "precaution" with $43 \%$ and then "victims" with $18 \%$, followed by danger $(17 \%)$, solidarity (11\%), and insecurity (8\%). The number of hope $(1 \%)$ and neutral $(2 \%)$ tweets remained at a very low level. Of the 1118 tweets coded in total, 481 were coded as 'precaution', 200 as 'victims', 185 as 'danger', 120 as 'solidarity', 93 as 'insecurity', 22 as 'neutral', and 17 as 'hope'. As stated above, the presence of distrust and danger categories among the most interacted tweets draws attention. 
Looking at the outstanding examples in the comparison of risk perception of different accounts, it is seen that the BBC Turkish singles out the perception of insecurity. This is pertinent to BBC tweets arguing that the number of cases is higher than what government announces, because of the numbers stipulated by the Turkish Medical Association. This is intensified through interviews with unidentified doctors, who are claiming that there is a shortage of equipment in intensive care units and the services cannot handle the patient density, as well as posts that create a sense of danger. The DW Turkish also report similar themes of danger, fear, and insecurity to those of the BBC Turkish. Distrust of numbers announced by the Ministry of Health, criticism of transparency, and claims that authoritarianism will increase with direct state intervention in internet use, constitute the main themes of danger and mistrust risk factors.

All in all, distrust and danger tweets are statements that contradict the statements of the authorities managing the crisis in the process and make the statements of the authorities debatable at the public level. The production of such content and the creation of serious interaction by circulating it on social media pose risks in terms of crisis communication and management of the pandemic. While such serious adversities are experienced on a global scale in processes that concern human health, such as a pandemic, the production of insecurity and danger-oriented content also undermine the information flow (infodemia) and trust in authorities.

Keywords: Coronavirus, Social Media, BBC Türkçe, DW Türkçe, Independent Türkçe, Content Analysis.

Bu makale intihal tespit yazılımlarıyla taranmıştır. Intihal tespit edilmemiş̧tir.

This article has been scanned by plagiarism detection softwares. No plagiarism detected.

Bu çalışmada "Yükseköğretim Kurumları Bilimsel Araştırma ve Yayın Etiği Yönergesi” kapsamında uyulması belirtilen kurallara uyulmuştur.

In this study, the rules stated in the "Higher Education Institutions Scientific Research and Publication Ethics Directive" were followed. 